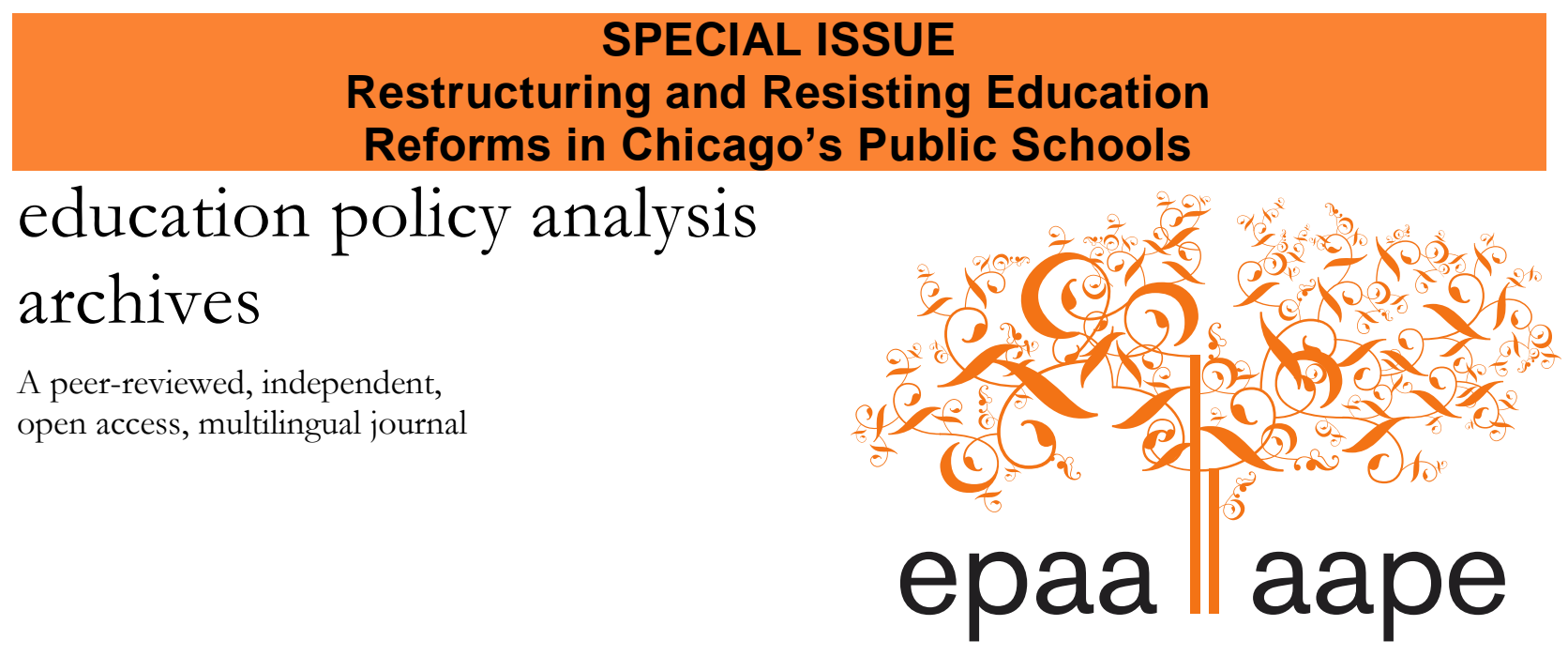

Arizona State University

\title{
School Choice or the Politics of Desperation? Black and Latinx Parents of Students with Dis/abilities Selecting Charter Schools in Chicago
}

\author{
Federico R. Waitoller \\ \&o \\ Gia Super \\ University of Illinois at Chicago \\ United States
}

Citation: Waitoller, F. R., \& Super, G. (2017). School choice or the politics of desperation? Black and Latinx parents of students with dis/abilities selecting charter schools in Chicago. Education Policy Analysis Archives, 25(55). http://dx.doi.org/10.14507/epaa.25.2636 This article is part of EPAA/AAPE's Special Issue on Restructuring and Resisting Education Reforms in Chicago's Public Schools, Guest Edited by Dr. Federico Waitoller and Rhoda R. Gutierrez.

Abstract: In this paper, we focus on the city of Chicago to examine how Black and Latinx parents of students with dis/abilities ${ }^{1}$ engage with school choice. Using analytical tools from

\footnotetext{
${ }^{1}$ We used the term dis/ability with a slash "to denote dis/ability not as an individual trait, but rather a social construction-the product of cultural, political, and economic practices. This understanding does not deny biological and psychological differences, but emphasizes such differences gain meaning, often with severe negative consequences (e.g., segregation), through human activities informed by norms. Dis/ability is also an 
grounded theory (Strauss \& Corbin, 1990) and a theoretical lens informed by critical notions of space, race and dis/ability, we analyze interviews with parents of students with dis/abilities, field notes, and various artifacts from charter schools (e.g., student handbooks and websites). We found that parents engaged with the politics of desperation (Stovall, 2013): an assemblage of thoughts and rationales to make school decisions amid poor and ableist educational options for Black and Latinx students with dis/abilities. We found that the neoliberal restructuring of urban education space was a driving force shaping parents' engagement with the politics of desperation. Thus, our study sheds light on the relationship between race, dis/ability, and urban spatial restructuring.

Keywords: special education; disabilities; school choice, political economy, urban studies, charter schools

\section{¿ La elección de la escuela o la política de la desesperación? Padres de estudiantes afroamericanos y latinos con dis/capacidades elijen escuelas en Chicago}

Resumen: En este artículo, nos centramos en la ciudad de Chicago para examinar cómo los padres de estudiantes afroamericanos y latinos con dis/capacidades seleccionan escuelas. Utilizando herramientas de análisis de teoría fundamentada (Strauss \& Corbin, 1990) y un lente teórico informado por ideas críticas de espacio, raza y dis/capacidad, analizamos entrevistas con los padres de estudiantes con dis/capacidades, notas de campo y varios artefactos de escuelas (por ejemplo, manuales del estudiante y sitios de internet). Encontramos que los padres basaron sus elecciones escolares en la política de la desesperación (Stovall, 2013): un conjunto de pensamientos y racionales para tomar decisiones escolares en el medio de opciones educativas de pobre calidad y capacitistas. Encontramos que la reestructuración neoliberal del espacio urbano fue una fuerza impulsora que influenció como los padres vivieron la política de la desesperación. Por lo tanto, nuestro estudio ilumina la relación entre raza, dis/capacidad y la reestructuración del espacio urbano.

Palabras clave: educación especial; discapacidad; escuela de elección, la economía política, estudios urbanos, escuelas

Será que a escolha da escola ou política de desespero? Pais de estudantes afro americanos e latinx com doença / habilidades que escolher escolas em Chicago

Resumo: Neste artigo, vamos nos concentrar na cidade de Chicago para examinar como pais de estudantes afro americanos e latinx com doença / habilidades selecionados escolas. Usando ferramentas de análise de teoria fundamentada (Strauss \& Corbin, 1990) e uma lente teórica informado por idéias críticas de espaço, raça e dis / capacidade, analisou entrevistas com pais de alunos com doença / habilidades, notas de campo e vários artefatos escolas (por exemplo, manuais de estudante e sites). Descobrimos que os pais comprometidos com a política do desespero (Stovall de 2013): um conjunto de pensamentos e racional da escola através inepto e capacitistas opções educacionais para Africano-americanos e estudantes latinx com doença / habilidades de tomada de decisão. Descobrimos que a reestruturação neoliberal da educação espaço urbano era uma força motriz moldar o envolvimento dos pais com a política de desespero. Portanto, nosso estudo lança luz sobre a relação entre raça, dis / capacidade e reestruturação espacial urbana.

Palavras-chave: educação especial; deficiência; escola de escolha, economia política, estudos urbanos, escolas

identity marker, which includes ways notions of ability are relied upon and constructed in tandem with other identity markers (e.g., gender, race, and language)" (Waitoller \& Thorious, 2016, p. 367). 


\section{School Choice or the Politics of Desperation? Black and Latinx Parents of Students with Dis/abilities Selecting Charter Schools in Chicago}

Neoliberalism has dramatically changed how school districts provide educational services. Grounded in the principles of deregulation, competition, and privatization, neoliberalism is an ideology for capital expansion that has substantially altered the organizing principles of social provisions (e.g., public education) across the public sector (Ball, 1997). Neoliberalism's solution to historical educational inequities is to unleash market forces, which are assumed to be both neutral and spontaneous (Apple, 2001).

School choice is a cornerstone of neoliberal educational reforms. One assumption informing school choice is that parents behave as rational consumers who, when given the "right information" (e.g., academic test scores, graduation rates, and dropout rates), will select the best school for their children. As many charter advocates have stated, when schools do not perform, parents can "vote with their feet" by moving to a better school. Over time, this consumer behavior will improve the quality of schools because (a) schools will strive to improve their quality to compete for students and (b) schools that do not perform will be weeded out, leaving only the best schools in operation (Chubb \& Moe, 1990; Manno, Finn, \& Vanourek, 1999). By this logic, schools are closed due to poor performance or decreasing student enrollment as parents choose different schools. However, these assumptions about school choice have been challenged, as parents make school decisions based on a much wider set of factors than school academic quality (Lubienski \& Weitzel, 2010). They may consider location, the commute, the demographics of neighborhoods and schools, and other information available to them (Ball, 2006; Bell, 2009; Garcia, 2008; Rowe \& Lubienski, 2016). In addition, the way these factors are considered differs across race and economic class lines (Lubienski \& Weitzel, 2010). For instance, research suggests that white parents perceive schools with high enrollment of minority populations as academically inferior even when academic data do not support such a conclusion (Lubienski \& Weitzel, 2010).

Charter schools are a key component of school choice. From the 1999-2000 to the 20112012 school years the student enrollment in charter schools has increased from 0.3 to 2.1 million students, accounting for $4.2 \%$ of the total national student enrollment in public schools (National Center for Education Statistics [NCES], 2014). In 2011-2012, 10.5\% of students enrolled in charter schools received special education services (Rhim, Gumz, \& Henderson, 2015). Enrollment in charter schools can be expected to increase as the Every Student Succeeds Act (2016) establishes funding for expanding high-performing charter schools and the newly elected president has promised a 20 billion dollar investment to expand school choice, including charter schools ("Education: Donald J. Trump's vision," 2016).

Despite the growth of charter schools, research on students with dis/abilities attending such schools has been limited in breadth and depth (Garcy, 2011;Waitoller, Maggin, \& Trzaska, in press). This limited research has mostly been published in non-peer-reviewed outlets (e.g., reports from think tanks, governmental, and advocacy groups) and has presented contradictory findings. On the one hand, students with dis/abilities attending charter schools spend more time in the general education classroom than their counterparts in traditional public schools (Rhim et al., 2015; Setren, 2015; Wilkens, 2011). There is also a small amount of evidence indicating that attending a charter school decreases the likelihood that a student will be identified for special education services (Winters, 2015), and increases their academic achievement and their graduation rate (Setren, 2015). On the other hand, charter schools have historically enrolled lower proportions of students with dis/abilities in comparison to neighborhood schools, particularly those with more severe dis/abilities (Waitoller et al., in press; GAO, 2012). In addition, anecdotal accounts of "steering away 
mechanisms" suggest that charter schools implicitly suggest that parents move their children to other schools (Welner \& Howe, 2005). Steering away mechanisms enacted by charter schools can include but are not limited to the following: communicating to parents that the school does not have the services the child requires, applying repetitive disciplinary measures to students (e.g., suspensions), or not providing the services required in the student's Individualized Education Plan (IEP) (Estes, 2006; Welner \& Howe, 2005). Supporting these accounts is the fact that charter schools suspend students with dis/abilities at higher rates than non-charter schools (Losen, Keith, Hodson, \& Martinez, 2016). These inequities have resulted in several court cases against charter schools for not following federal regulations protecting students with dis/abilities (e.g., Southern Poverty Law Center v. Pastorek, 2010). In contrast to these findings, survey research suggests some parents of students with dis/abilities choose charter schools due to their small class size, parents' perceptions of special education services at the charter school, dissatisfaction with a prior school, and to avoid identification for special education and subsequent segregation (Lange \& Lehr, 2000; Rhim \& McLaughlin, 2007).

Yet, school choices are not made in isolation. For students of color with dis/abilities living in urban areas these choices are carried out amid historical and compounding forms of exclusion in public schools (Blanchett, Klingner, \& Harry, 2009). Among these inequities, we can include lack of access to the general education curriculum, to meaningful learning experiences due to inadequate personnel and funding resources, and to related services (e.g., speech and occupational therapy, counseling, and social work). Further, parents of color experience limited opportunities to participate in key educational decisions such as those made during IEP meetings, as well as marginalization due to their identities as low-income parents of color (Harry \& Klingner, 2006; OngDean, 2009). In addition, the disproportional representation of Black, Latinx, and Native American students in special education continues to be an unresolved conundrum (Skiba, Artiles, Kozleski, Losen, \& Harry, 2015). Thus, school choice is implemented in a context fraught with historical legacies of racism and ableism.

Thus, it is important to understand how parents of students with dis/abilities make school selections in urban contexts. Focusing in the city of Chicago, the present study examines how choice, particularly when it comes to selecting a charter school, plays out with Black and Latinx parents of students with dis/abilities. The study focuses on how parents' decisions are contextualized and affected by the neoliberal restructuring of urban space. In the following sections, we present our theoretical framework, examining the role of neoliberalism in restructuring urban space in Chicago and its implications for services provided to Black and Latinx students with dis/abilities. Then we describe our research methods, present our findings and discuss them, drawing from our theoretical framework.

\section{Neoliberalism, Race, and Dis/ability and the Restructuring of Urban Space in Chicago}

To understand how parents make schooling decisions for their children with dis/abilities we draw from an interdisciplinary critical lens that foregrounds the role of urban space restructuring (e.g., Brenner \& Theodore, 2002 Harvey, 2006; Soja, 1989) at the intersection of education, race, and dis/ability (e.g., Annamma, Connor, \& Ferri, 2013; Lipman, 2011). As we describe this lens, we provide examples from Chicago, which has been a laboratory for testing neoliberal reforms on working class communities of color, as Lipman (this special issue) describes in detail.

We understand space not merely as a container or stage but as an active ecology that mediates and is mediated by human activity (Soja, 2010). Space is produced through economic, social, 
political, and cultural practices (Harvey, 2006). In turn, this produced space shapes how humans individually and collectively engage in such practices (Soja, 1989). For instance, when selecting a school, parents may consider access and proximity to home or work or they may choose according to neighborhood and school demographics and their perceptions of such demographic groups (Bell, 2009; Garcia, 2008). These spaces are not natural, but they are the products of human activity and of decisions such as where to locate or dismantle public housing, what areas of the city are worth investment, where to increase police surveillance, and how to draw school attendance boundaries.

The production of space, both locally as well as globally, is deeply impacted by neoliberal ideology and governance. When presented with complex social issues like unemployment or unequal access to quality education, neoliberalism responds with a "spatial fix," changing the urban landscape to make way for capital accumulation (Harvey, 2008). Yet, capital investment is distributed asymmetrically within an urban space, creating both centers and peripheries. So the production of space becomes both uneven (Brenner \& Theodore, 2002) and unjust, which Harvey (2008) calls uneven geographical development. Thus, power differentials are always at play in the production of space. Those with the power to orchestrate the production of space do so to further accumulate economic and social resources (Soja, 2010).

Relatedly, urban space is produced through a process of creative destruction (Brenner \& Theodore, 2002). This process involves two intertwined and distinct moments: (a) a moment of destruction of institutional arrangements that were based on a Keynesian provision of social goods and services (e.g., public housing, education, and labor protections), and (b) a moment of creation of new infrastructures and arrangements based on and for market-oriented economic growth (Brenner \& Theodore, 2002). Both moments are mobilized through distinctively geographical and racial strategies affecting major institutional arenas such as education and public housing (Smith \& Stovall, 2008; Lipman, 2011). Accumulation of capital and power in the hands of a few is achieved by dispossession of public land and social services (Harvey, 2005). Both processes of uneven geographical development and creative destruction are planned and orchestrated through state intervention (Soja, 1989).

Neoliberalism and racism contribute to each other's ideological expansion. Racism continues to provide the justification for the exploitation of people of color, now under the banner of neoliberalism (Omi \& Winant, 2015). Neoliberalism builds upon preexisting structures of racial and economic inequities, leaving the city with areas of both under- and over-development demarked by racial lines (Harvey, 2008; Lipsitz, 2007). Low income and working class communities of color and the spaces where they live are dispossessed of social services such as education and public housing to create opportunities for capital expansion and for the return of more affluent families to the city (Stovall, 2013; Harvey, 2005). For instance, urban centers like Chicago aim to become global cities, which concentrate financial institutions and corporate interests (Sassen, 2005). In these cities, the juxtaposition of wealth and poverty is inscribed in the racially and economically segregated geographies of their urban landscapes. While some areas of the city_often predominately whiteare revamped to attract corporate headquarters and a highly educated labor force, areas inhabited by communities of color are pathologized, experiencing disinvestment, multi-generational poverty, and economic decline. Further, in other areas of the city, low-income and working class communities are displaced due to gentrification. Racist ideology is used to justify the revamping of certain areas of the city and the disinvestment in communities of color and consequently the perpetuation of Whiteness (Buras, 2011; Lipsitz, 2007). By Whiteness, we refer to "an analytic category that refers to the structured advantages that accrue to whites because of past and present discrimination" (Lipsitz, 2007, p. 13). Thus, this spatial restructuring is another chapter in the history of the relationship between whiteness and capital expansion dating back to slavery (Robinson, 2000). 
On the other hand, neoliberalism reinforces racism. Neoliberalism recognizes inequitable outcomes along racial lines. Yet, it explains them as the result of individual and group choices (Omi \& Winant, 2015). Dumas (2013) wrote.

Through the neoliberal-multicultural lens, we can still feel sympathy to the extent that these subjects are perceived as being prevented from participating in the market. However, if they reject opportunities to participate in the market, no matter how rigged that system may be, then our sympathies can be justifiably withheld. (p. 535).

According to neoliberal ideology, race does not determine one's success-one's capacity to produce and consume does (Davis, 2007). The neoliberal emphasis on individual responsibility and choice eclipses the historical legacies of racism inscribed in the segregated geographies of urban centers, blocking claims for racial justice. For instance, researchers have found that charter schools either reflect or exacerbate patterns of racial segregation in schools (Fabricant \& Fine, 2012; Lubienski \& Weitzel, 2010). However, these patterns are understood as the result of parents' choice, masking the historical and structural legacies of racisms and blaming communities of color for their living situations.

Chicago provides a clear example of the relationship between the neoliberal restructuring of urban space, race, and public school policies (Lipman, 2011). Starting with the Richard Daley administration in the mid-1990s and continuing during the current Emanuel administration (2011present), Chicago Public Schools (CPS) has deployed a series of neoliberal educational reforms. Most prominent, in 2001 Arne Duncan, who later became U.S. Secretary of Education, was appointed as CEO of CPS. Building upon the work of his predecessor Paul Vallas, Duncan implemented an intense school choice agenda and encouraged the expansion of charter schools. Three years later and engineered and pushed by the Commercial Club of Chicago ${ }^{2} \&$ the Daley administration, the Chicago school board passed Renaissance 2010 (Ren2010), a plan to revamp CPS that called for closing and turning around more than 70 neighborhood schools and opening 100 new schools, most of which were charter schools (Lipman, 2011). By 2016, the number of charter schools in Chicago had increased dramatically. There are more than 120 charter campuses serving almost 54,000 students (14\% of the district's total enrollment), from which over 7,500 are students receiving special education (CPS, 2016a). In addition, CPS “turned around" over 30 and closed more than 100 schools, with 50 schools closed in the 2013-2014 school year alone. Turning around a school involves replacing all school staff (that is, principal, teachers, counselors and administrative staff) and in some cities like Chicago, it may involve turning over the school to a private education management organization. While the closings during the Daley administration were rationalized on the grounds of school underperformance, during the Emanuel administration school closings were justified as austerity measures to "right size" the district due to declining student enrollment.

The areas of Chicago with concentrations of school closings overlap with areas where charter schools have proliferated (see Figure 1). In these areas, the cumulative effects of school closings and turnarounds, along with the opening of charter schools, disproportionally impact the south and southwest areas of the city, where low income and working class Black and Latinx students live and attend school. Schools with larger proportions of Black students "had a higher probability of closure than schools with comparable test scores, locations, and utilization rates" (Caref, Hainds, Hilgendorf, Jankov, \& Russell, 2012; Weber, Farmer, and Donoghue 2016, p. 1).

${ }^{2}$ The Commercial Club of Chicago is an organization of the city's most powerful financial and corporate elites in the city of Chicago. 


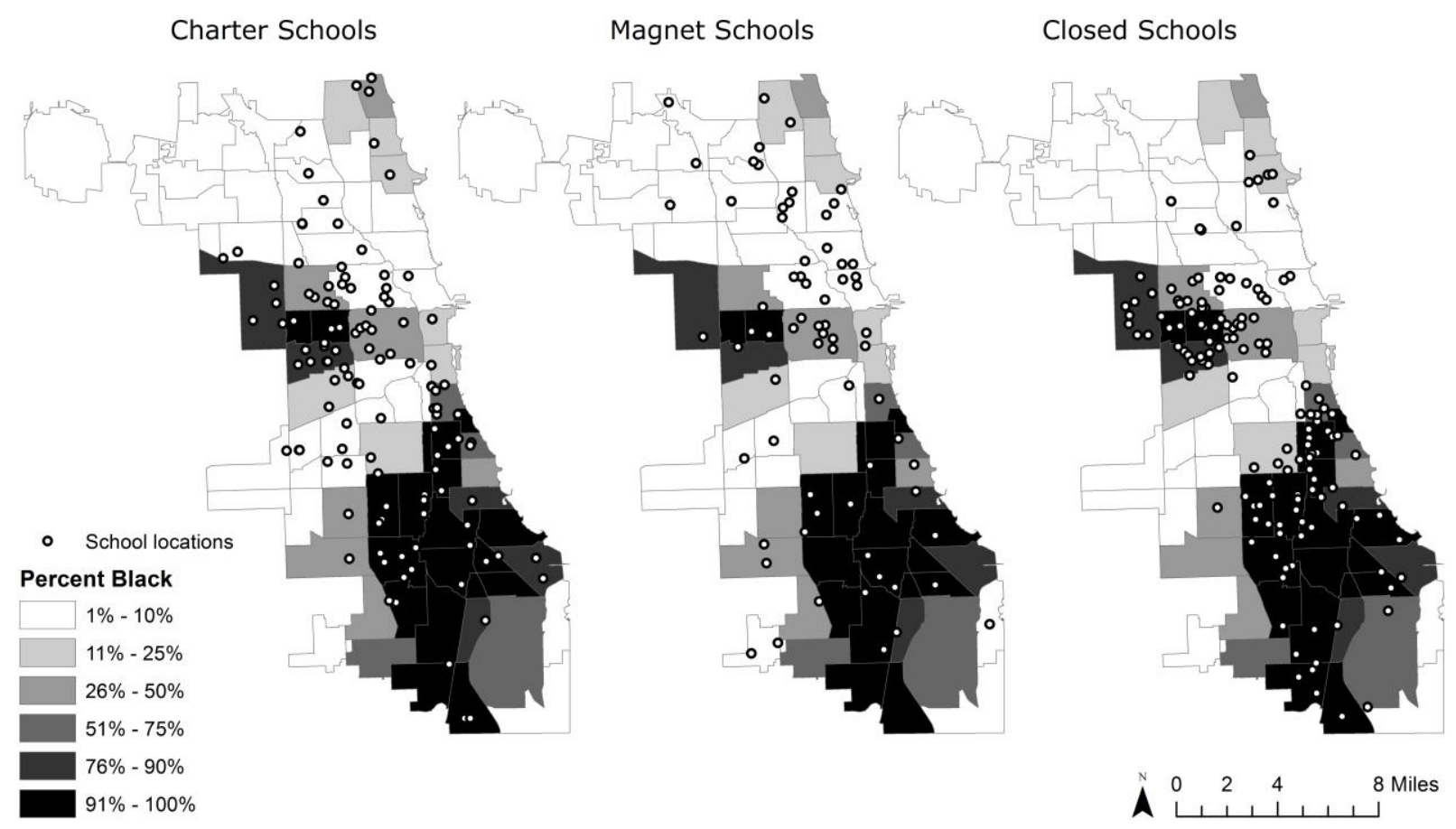

Figure 1. Location of charter and magnet schools in the city of Chicago 2013-2014, school closings from 2000 to 2015, and distribution of Black population.

When schools are closed, students are transferred. Some Black students were transferred to up to four schools within a three-year period and the schools receiving students from closed schools were not performing academically better (Gwynne \& de la Torre, 2009). Further, more than school closings, turnaround schools tended to disproportionally affect Black students (Weber et al., 2016). Charter schools are also located primarily in low-income and working class Black and Latino neighborhoods in the west and southwest and south areas of Chicago (see Figure 1). While Black students account for $38 \%$ of the total CPS enrollment, they account for $53 \%$ of the total enrollment in charter schools (CPS, 2016a). The historical disinvestment in neighborhood schools (See Lipman, in this special issue) and the opening of charter schools are manifestations of the neoliberal process of creative destruction (Brenner \& Theodore, 2002). Over time, the closing of neighborhood schools and the opening of charter schools (as well as other types such as selective enrollment schools) reshape the urban education space, disproportionately affecting low-income communities of color. Meanwhile, areas in the city that are predominately white remain unaffected or receive new well-resourced schools in the form of selective enrollment or magnet ${ }^{3}$ schools. So while neoliberal education polices maintain and protect whiteness, they dismantle and destabilize educational opportunities for Black and Latinx students (Lipman, 2011).

The deployment of these reforms coincides with a development boom in downtown Chicago and adjacent areas (Weber, 2015). Starting in the late 1990s, the city expanded retail and office spaces in the city center and brought in large corporations through tax incentives (Weber, 2015). Schools were seen as a key component in this restructuring of the city space (Lipman, 2011).

\footnotetext{
${ }^{3}$ A magnet school is a public school without attendance boundaries that offers a special curriculum and programs that are not available elsewhere.
} 
The closing of neighborhood schools and their reopening as selective enrollment schools occurred in what sociologists have called the "zone of transition" (Lipman, 2011; Smith \& Stovall, 2008): prime real estate located within a 6-mile radius of the city center (Weber, et al., 2016). CPS closed schools for low enrollment in Latino communities being gentrified, despite counterevidence of such low enrollments (Fleming, Greenlee, Gutstein, Lipman, \& Smith, 2009; Greenlee, Hudspeth, Lipman, Smith, \& Smith, 2008). These schools were replaced with selective schools advocated by affluent parents moving to those areas (Lipman, 2011). Thus, closing and turning around schools achieve the symbolic work of transforming the perceptions of previously pathologized city areas so that more affluent families will move to them rather than relocating in the suburbs. It is not that developers are racist, but rather "their contribution to a system of displacement contributes to a larger racist system, centered in making the city 'safe again' for its returning white residents" (Smith \& Stovall, 2008, p. 149). Thus, legacies of racisms shape what may appear to be a technical and raceneutral metric for closing or turning around a school based on low performance or underutilization. The neoliberal restructuring of the urban space is a racial project that aims to contain and displace low income and working class communities of color for the sake of capital expansion (Lipman, 2011; Omi \& Winant, 2015). Yet, as we discuss in the next section, the neoliberal restructuring of the urban space is not only a project about race, but woven in its fabric is also an enduring thread of ableism.

\section{Special Spaces: Neoliberal-ableism and Black and Latinx Students with Dis/abilities}

Though it remains largely unexamined in the political economy of education, neoliberalism is an abliest project. Neoliberalism aims to nurture productive workers who contribute to capital production and accumulation in the global economy. Children, youth, and adults are expected to overcome misfortunes and austerity measures that cut social and educational services, while adopting ableist ideals that are confined to narrow and individualistic conceptions of personhood that privilege autonomy, independency, and entrepreneurship (Goodley, 2014). Individuals are measured in terms of their economic value, which trumps values based on human rights and dignity. Goodley (2014) named this identity project neoliberal-ableism, arguing that individuals become normalized through economic and social policy and judged by the neoliberal ideal of human beings. Any physical and mental inclination to interdependency creates grounds for anxiety and intervention, as they are perceived as threats to economic productivity (Shildrick, 2012).

In education, this push for normalizing bodies according to neoliberal ideals of personhood has contributed to the emergence of a selective inclusionism (Mitchell, 2015; Waitoller, in press). By inclusionism, we refer to the activity of including children and youth with dis/abilities in schools without altering the institution's norms of belonging and being or its neoliberal fantasies of normative productive bodies (Mitchell, 2015). This inclusionism is also selective; it only provides access for those bodies whose differences are integrable to normative practices. This select group of integrable students is then pushed to conform to narrow molds of human development and learning informed by smartness and goodness - the ideologies that delineate hierarchies of who is smart and good and who is not, setting normative parameters for what students should be able to know and do and for how to behave in school (Broderick \& Leonardo, 2016; Hatt, 2012). For instance, students with dis/abilities may be expected to learn the same content and skills, at the same pace, in the same year as any other student, reaching certain educational milestones that are supposed to guarantee college-readiness, independence, and status as a contributor to the global economy. Like whiteness, smartness and goodness act as property (Broderick \& Leonardo, 2016; Harris, 1993). Those who can 
claim smartness and goodness enjoy the benefits of participating in a market model of education, and their associated economic benefits (e.g., gain employment).

Selective inclusionism shapes and is constituted by the restructuring of urban space. First, the design of efforts to restructure the urban space tends to ignore students with dis/abilities, creating normalizing spaces where students with dis/abilities are an afterthought. These students then need to be accommodated and thrive within school spaces that are exclusionary by design. Going back to Chicago, for instance, the design of Ren2010 completely overlooked students with dis/abilities. Requested by CPS officials, The Illinois Facilities Fund (IFF) ${ }^{4}$ published a report a few months after CPS rolled out Ren2010, examining numerous demographic variables to make a case for many of the Ren2010 efforts. This report completely omitted any variable related to the education of students with dis/abilities. This foundational report for Renn2010 established the basis for the absence of innovative approaches for teaching and including students with dis/abilities in the proposals for new schools during Ren2010 (Estevan, 2009). Indeed, an examination of these proposals found that there was little to no attention to services tailored for students with dis/abilities such as specialized instruction or transition to out-of-school services, among others (Estevan, 2009).

Second, through neoliberal education reforms, students with dis/abilities are expected to overcome exclusion and improve their academic performance amid continuing and increasing austerity measures that drain resources from schools. For instance, disinvestment and destabilization of neighborhood schools in Chicago has deeply affected special education services. Though the enrollment of students with dis/abilities in CPS has increased, the district has engaged in a series of efforts to "right-size" special education. In July 2015, CPS released a school budget reducing its funds by 200 million from which 42.3 million (21\%) were cut from special education funding. Schools with higher percentages of students with dis/abilities than the district average $(12 \%)$ were hit the hardest, experiencing a reduction of 656 positions, while the remaining schools only experienced the loss of 26 positions (Chicago Teachers Union, 2015). According to CPS, this was implemented after an 18-month review of staffing and services for students with dis/abilities, though CPS never made publically available the documents used for this evaluation. After much pushback from principals, parents, teachers, and dis/ability advocacy organizations, CPS restored 150 special education positions in November, once classes were well on their way. CPS explained at that point that the formula used in the prior budget was flawed, and as part of these changes, Markey Winston, CPS director of special education, resigned due to this budget error. Principals had to readjust their personnel and schedules in the middle of the school year, which made it difficult to find qualified personnel at that time (Estevan, 2016). There were more cuts to the special education budget conducted in 2016, which are beyond the scope of this paper, but that continued to demonstrate the disinvestment and destabilization experienced in special education services in the city of Chicago.

Amid this disinvestment and destabilization, students with dis/abilities deemed as integrable are expected to comply with normative standards of learning, perform similarly to their peers, and be college ready in schools that are designed to exclude them. Current CPS CEO Forrest Claypool's words illustrate this point. In a board meeting on December 2016 when discussing the budget cuts affecting special education, Claypool expressed, "The purpose of special education is to help the majority of kids develop the skills through alternative learning techniques, diverse learning techniques to overcome their dis/abilities for life" (CPS, 2016b). In other words, as neoliberal

${ }^{4} \mathrm{IFF}$ is an organization that engages in finance planning and real estate development in IL and was one of the early supporters of charter schools. 
subjects, they need to become smart and good, producers and consumers in the market economy despite the continuing disinvestment and prejudice resulting from neoliberal policies.

Selective inclusionism affects particularly Black and Latinx students with dis/abilities. To understand these effects at the intersections of race and dis/ability we draw from Disability Studies and Critical Race Theory in Education (DisCrit; Annamma et al., 2013). Building from intersectionality theory (Crenshaw, 1991), DisCrit is based on the premise that notions of race and ability are co-constructed, "race, racism, dis/ability and ableism are built into the interactions, procedures, discourses, and institutions of education, which affect students of color with dis/abilities qualitatively differently than white students with dis/abilities" (Annamma et al., 2013, p. 7). DisCrit affords a nuanced analysis of how structural privilege informed by whiteness, smartness and goodness interact, affecting students of color with dis/abilities in particular ways. As Broderick \& Leonardo (2016) explain, education is racialized to reinforce the goodness and smartness of whiteness, as race is part of how schools perceive and construct students' identity around notions of intelligence and good behavior.

In Chicago, Black and Latinx students with dis/abilities have been impacted by the restructuring of urban space to a greater extent than their Black and Latinx peers without dis/abilities and more than white students with dis/abilities. For instance, the average proportion of students with dis/abilities in the closed schools in 2013-2014 was 17\% compared to the proportion of students with dis/abilities in the entire district of only 13\% (de la Torre, Gordon, Moore, \& Cowhy, 2015). Of the 50 schools closed in 2013-2014, one third had special education programs serving Black students with extensive support needs (i.e., autism, intellectual dis/abilities, multiple dis/abilities, sensory impairments). These programs had provided services, personnel and resources, and low teacher-student ratios to better serve the individual needs of these students. In addition, many Black and Latinx parents of students with dis/abilities found that the school that received them after their school was closed did not have adequate services to meet their children's needs. Thus, parents had to search for yet another school in the middle of the school year (de la Torre et al., 2015).

Further, charter schools are not likely to be an option for those students considered difficult to integrate, as Chicago charter schools tend to enroll a selective group of students with dis/abilities (Waitoller et al., in press). Chicago charter schools enroll disproportionately lower rates of students with dis/abilities who require more extensive educational supports (e.g., specialized teachers, assistive technologies, one-on-one assistance, and occupational therapy), while enrolling significantly higher proportions of students with learning dis/abilities (LD) (Waitoller et al., in press). As commodities, students of color with dis/abilities with extensive support needs not only cost more to educate, but they produce lower test scores, diminishing the symbolic status of a school.

Thus, closing neighborhood schools and opening charter schools directly decreases school options for Black and Latinx students who require more extensive supports to be included in schools. While neighborhood schools provide guaranteed access to a school near students' homes, charter schools work on a lottery system, which does not guarantee services near students' residences. Furthermore, this lottery system is sometimes trumped by steering away mechanisms, discussed above. Students of color with dis/abilities who are deemed more integrable and who fit within the normative practices of a charter schools can have access to such spaces. Other students who cannot learn and thrive in such environments experience further marginalization and shrinking school options. So, while white students with dis/abilities enjoy the benefits of whiteness as they lived in areas of the city benefited by the neoliberal restructuring of urban space, and while some Black and Latinx students may enjoy the benefits of claiming smartness and goodness as property (i.e., being considered integrable to charter schools or selective enrollments), Black and Latinx 
students with dis/abilities cannot claim neither whiteness, smartness, nor goodness, and are oppressed by the intersections of these three ideologies.

Further, the neoliberal restructuring of the urban education space builds upon prior inequities at the intersections of race and dis/ability. Chicago Public Schools have a troubling history of serving Black and Latinx students with dis/abilities. The district has been the focus of textbook court cases for discriminating against and segregating students with dis/abilities, particularly those who are Black. For instance, in Corey H. v. Chicago Board of Education (1992), CPS was found responsible for segregating students with dis/abilities solely on the bases of their dis/ability classification rather than on their individual needs, violating core provisions of the Individuals with Disability Education Act (IDEA). Though the Corey H. case was closed in 2012, CPS continues to segregate students with dis/abilities, most of whom are Black and Latinx, at a higher rate than national averages (see Table 1). The neoliberal restructuring of the urban education space can further segregation by pushing students of color with dis/abilities out of selective enrollment and charter schools, and concentrating them in self-contained classrooms in neighborhood or special schools. Simultaneously, it pushes students of color with dis/abilities deemed as integrable into the general education setting without transforming those exclusionary spaces in order to reduce or "right size" special education services.

Table 1

Percentage of students with dis/ abilities included in the general education classroom for more than $80 \%$ of the school day in selected categories (2013-2014 school year)

\begin{tabular}{lcc}
\hline Disability Category & CPS & US \\
\hline Autism & $25 \%$ & $40 \%$ \\
Emotional Disability & $40 \%$ & $45 \%$ \\
Intellectual Disability & $5 \%$ & $17 \%$ \\
Other Health Impairment & $63 \%$ & $65 \%$ \\
Specific Learning Dis/ability & $54 \%$ & $69 \%$
\end{tabular}

Note: Data retrieved from the Illinois Special Education Profiles at

http://webprod.isbe.net/LEAProfile/SearchCriteria1.aspx and the 37th annual report to Congress on the implementation of IDEA (U.S Department of Education, 2015).

The issues discussed in this section underscore the significance of analyzing the implications of neoliberal education policies with clear consideration of intersections of race, dis/ability, and spatial restructuring. Living in the educational context described in this section, parents of Black and Latinx students with dis/abilities may understand and engage with school choice and charter schools in particular ways. Considering the role of space in shaping human activity (Soja, 2010), it becomes critical to ask how these parents experienced choice amid the restructuring of urban education space and how the economic restructuring of the city shaped their school selection. Thus, our research questions are the following: 
1. What are the factors that shape Black and Latinx parents of students with dis/abilities decision of enrolling their child in a charter school?

2. How are these factors related to the restructuring of the urban space?

\section{Methods}

The present study presents a section of the findings from a larger research study that aims to examine the experiences of Black and Latinx parents of students with dis/abilities in selecting a charter school and experiencing conflict in such school. The study was conducted through a partnership with Disability Legal Advocates (DLA: pseudonym) a civil rights non-profit agency that provides legal advice, support, and representation to individuals with dis/abilities.

\section{Participants}

Participants were selected using a purposive sample to provide information that was relevant to our research questions (Payls, 2008). Study participants included Black and Latinx parents of students with dis/abilities who have attended a charter school in the city of Chicago and have received legal services from the Charter School Clinic at DLA. Studying the experiences of parents served by this agency guarantees us that our participants had enrolled in a charter school and were making school choices beyond that of their neighborhood school, and that they experienced conflict with the charter school.

Recruitment occurred in two phases. First, using a phone script provided by the researchers, staff at DLA contacted by phone all their Black and Latinx clients served in the prior year. We focused on cases from the most recent year to capture the most up-to-date and relevant issues, considering that charter schools are increasingly enrolling students with dis/abilities and their demographics and practices are changing (Rhim et al., 2015). DLA Staff explained the study to potential participants and those who were interested in participating in the study were given two options that were not mutually exclusive: (a) they could give DLA consent to pass their contact information (i.e., name and phone number) to the researchers for a follow up call, or (b) they would be given the researchers' phone number and email so they could initiate contact. Out of 77 possible cases, 29 parents or guardians agreed to be contacted by a researcher, while four additional potential participants contacted the researcher directly, adding up to a total of 33 potential participants.

Second, the researchers established contact with the potential participants and invited them to participate in the study. Of the 33 potential participants, we were able to interview 24 (see Table 2). The main reason for not interviewing the nine remaining cases was that an interview could not be arranged with the participant and over time the participant stopped communicating with the researchers. 
Table 2

Characteristic of Study Participants and Their Children

\begin{tabular}{|c|c|c|}
\hline & $\begin{array}{l}\text { Children } \\
(N=24)\end{array}$ & $\begin{array}{c}\text { Parents/Caregivers } \\
(N=24)\end{array}$ \\
\hline \multicolumn{3}{|l|}{ Race } \\
\hline Latinx & $17 \%(4)$ & $17 \%(4)$ \\
\hline African American & $75 \%(18)$ & $83 \%(20)$ \\
\hline Biracial & $8 \%(2)$ & 0 \\
\hline \multicolumn{3}{|l|}{ Gender } \\
\hline Male & $75 \%(18)$ & 0 \\
\hline Female & $25 \%(6)$ & $100 \%(24)$ \\
\hline \multicolumn{3}{|l|}{ Areas of the City ${ }^{5}$} \\
\hline Middle Class & -- & $17 \%(4)$ \\
\hline Gentrification & -- & $12 \%(3)$ \\
\hline Serious Decline & -- & $42 \%(10)$ \\
\hline Extreme Poverty & & $29 \%(7)$ \\
\hline \multicolumn{3}{|l|}{ Grade } \\
\hline Elementary & $50 \%(12)$ & -- \\
\hline Middle School & $25 \%(6)$ & -- \\
\hline High School & $25 \%(6)$ & -- \\
\hline \multicolumn{3}{|l|}{$\begin{array}{l}\text { Type of charter school } \\
\text { attended }\end{array}$} \\
\hline Franchise & $83 \%(20)$ & -- \\
\hline Stand-Alone & $17 \%(4)$ & -- \\
\hline Total & 24 & \\
\hline
\end{tabular}

${ }^{5}$ These areas of the city are based on the community typologies stablished in The Socioeconomic Change of Chicago's Community Areas (Nathalie P. Voorhees Center for Neighborhood and Community Improvement at the University of Illinois at Chicago [NVC], 2014). 


\section{Data Collection}

For the analysis presented in this paper, we used 24 in-depth interviews that we conducted over a period of four months. The 24 interviews were semi-structured and open-ended, lasting from 55 to 140 minutes, and largely at participants' homes (75\%), but also in public spaces like cafes and libraries (24\%) and one in the researcher's office. All interviews were audio recorded and transcribed for analysis. We substituted all identifiable information (names of parents, children, schools, school staff, neighborhoods, and streets) with pseudonyms.

We generated 24 field notes (one for each interview) of our observations from the interviews and any relevant conversations that were not captured in the recordings. These field notes contained information that the interview alone could not capture, including the context of the interview (e.g., setting, participants' appearance, body posture, facial expressions, initial contact, etc.) and our initial thoughts about the encounter with the participant.

In addition, we collected charter school artifacts (e.g., school applications, mission statements, student handbooks, and school histories from the charter school websites), and photographs of charter school advertisements that we found in the neighborhoods when we went to interview parents. These data serve to contextualized parent's responses about their perception of charter schools.

\section{Data Analysis}

To analyze our data we drew from methodological tools from grounded theory (Charmaz, 2008). First, we began by conducting initial coding on the 24 parent interviews, which included lineby-line, incident-by-incident, and In Vivo codes (Charmaz, 2008). The goal of this initial coding was to remain open and stay close to the data, while moving quickly through the transcripts, generating an initial list of codes and some analytical direction.

Second, we focus-coded these transcripts, selecting the codes that appeared more often and were the most relevant to our research questions. This step allowed us to synthesize larger sections of the transcripts. We refined focus codes by comparing and contrasting them, finding relationships among them, memoing and transforming them into conceptual categories (Charmaz, 2008). For instance, some examples of the conceptual categories that emerged earlier in the analysis were "unsafe neighborhoods" and "experiencing segregation."

Both of the authors coded 18 out of the 24 interviews (75\%) using these conceptual categories, meeting biweekly to discuss and compare coding until reaching 100\% coding agreement and refining the definitions of the categories. The authors coded the remaining interviews according to the agreement established in those meetings and wrote a memo for each interview describing the main aspects of the story told by the parent. These memos served later to shape the final explanatory models for choosing a charter school. We created summaries of the main aspects of each interview according to our ongoing analysis and called our participants to check our understanding of their stories, according to member check procedures (Lincoln \& Guba, 1985).

Using axial coding techniques (Charmaz, 2008) we clustered certain codes along particular axes, while deleting and renaming other codes as we compared and contrasted them, finding relationships among them. For instance, we clustered codes under larger conceptual categories such as "leaving the neighborhood school," "selecting a charter school" among others. Some axes clustered codes vertically (i.e., coding trees) while others horizontally to create theoretical categories that went beyond description and brought an analytical edge to the writing. For instance, while the conceptual category "unsafe neighborhoods" belonged to a larger conceptual category named "leaving a neighborhood school" and the category "strict discipline policies" was part of a coding tree named "the allure of charter schools", both of these codes were clustered horizontally under the 
theoretical category named "Searching for Safety.," which in turn become part of the overreaching concept titled "politics of desperation."

To examine whether and how the role of the restructuring of the urban space shapes parents' experiences in selecting and experiencing conflict in charter schools, we classified each participant using The Socioeconomic Change of Chicago's Community Areas (Nathalie P. Voorhees Center for Neighborhood and Community Improvement at the University of Illinois at Chicago [NVC], 2014). This report identifies and examines demographic and economic changes in Chicago's community areas from 1970-2010. The index was generated "from a set of thirteen empirically tested socioeconomic variables related specifically to gentrification. These variables measure shifts in poverty and wealth using five decades of US Census data" (NVC, 2014, p. 2). This analysis provides a community typology. We looked within this community typology to compare and contrast participants' experiences with the process of choosing schools and found common themes across participants living within similar community areas. We used the participants' addresses at the time they chose the charter school to code parents according to these socioeconomic categories, as we were interested in this particular instance of decision making. Figure 2 presents this typology and the distribution of charter, magnet and closed schools.

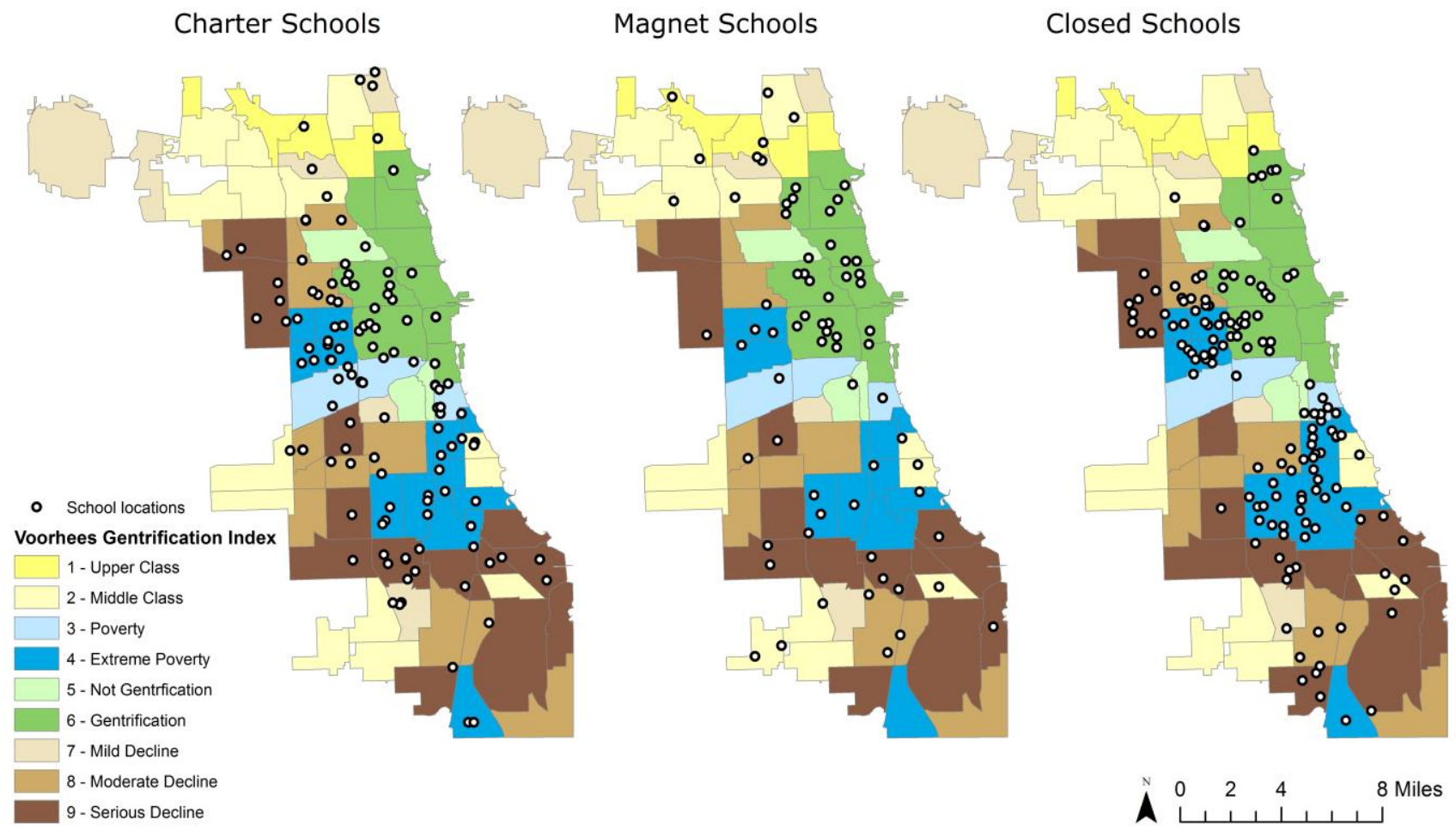

Figure 2. Community typologies (NVC, 2014) and location of charter and magnet schools and school closed 2000-2015. 
Throughout the analysis, we wrote memos about parents' experiences in selecting a charter school, refining our explanatory model and recoding some segments of data accordingly. This was an iterative process that involved going back and forth between our models, the data, and the literature on charters schools (e.g., Fabricant \& Fine, 2012; Lubineski \& Weitzel, 2010), political economy (Lipman, 2011; Stovall, 2013), and critical views of space (e.g., Harvey, 2006; Soja, 1989, 1996). This resulted in a sequential and deeper analysis that served as an intermediate step between coding and the first draft of the manuscript (Charmaz, 2008). Once a robust model emerged from our analysis, we went back to the interview transcripts, systematically searching for disconfirming cases. Throughout the process, including the design of the study, we debriefed (Lincoln \& Guba, 1985) with two colleagues: one with expertise in grounded theory, and another one with expertise in the political economy of education.

\section{Limitations of the Study}

This study has several limitations. First, our sampling strategies limited the transferability of our findings about how parents of students with dis/abilities select a charter school. Our larger study from which we extract the present analysis focused on the parents of students with dis/abilities who had conflicts with charter schools. Thus, our findings may only apply to those parents who are likely to struggle within the education system, not because of who their children are but rather because schools are not prepared to serve them. In addition, the sample only included parents who have the knowledge, resources, and time to seek legal services. We assume that there are many other parents who have similar experiences but do not have the time, knowledge, or resources to seek help, and may be falling through the cracks. Future research should broaden the pool of participants to include parents of students with dis/abilities who have good experiences in charter schools and also those who have not initiated any formal legal complaint. Comparison among these groups of parents will serve to better understand what contributes to providing quality services for students with dis/abilities in both charter and neighborhood schools.

Second, the large majority ( $83 \%$ ) of the charter schools included in this study were charter franchises (Fabricant \& Fine, 2012): "large non-profit operations that focus on a particular educational model and attempt to bring it to scale"; "this type of charter schools are replicated in a cookie cutter style across a district or nationally" (p. 22). There were a few participants who attended standalone or mom and pop charter schools (Fabricant \& Fine, 2012). Though this school sample can be considered a limitation, we must also note that franchise charter schools dominate the Chicago charter landscape. Future research should examine the experiences of parents of students with dis/abilities attending stand-alone charter schools.

Third, we did not continue to collect data over time. Thus, our findings represent parents' experiences up to the time of the interview. It is possible that those parents whose children are still in school may have found a suitable school for their children. It is worth noting, however, that 25\% of the students were in high school, either graduating or close to graduation, and $54 \%$ of the families decided to stay in the charter school after the conflict. Future research should study longitudinally the experiences of parents as they move through the market-driven education system.

\section{Findings: Politics of Desperation}

Due to their experiences in CPS schools or to what they had heard about and seen in those schools, Black and Latinx parents of students with dis/abilities made school selections by engaging in the politics of desperation. By the politics of desperation, we refer to "the complex assemblage of thoughts and actions that guide educational decisions in periods of housing and schooling uncertainty" (Stovall, 2013, p. 39). Stovall explains (2013), 
Because many families have experienced or are fearful of exposing their child to the worst that CPS has to offer, some families embrace a politics of desperation [...] It becomes important to note that the politics of desperation are based on an understanding of the peculiar realities around educational options in the city. (p. 39)

We noted that the politics of desperation did not represent a particular moment of decision-making. Participants struggled across their children's educational trajectory to find a school that could serve the individual needs of their children with dis/abilities. For instance, Shanell was a Black parent of a student with autism who was fighting against her child's initial placement in a segregated setting by CPS and was also concerned about his safety in the neighborhood school. During the interview she stated,

You know how people will make the comment the devil you know versus the devil you don't? People, they'll go with the devil you know versus the devil you don't? For me, I'd rather go with the devil that I don't because there's a possibility that it's not a devil. I was pretty much done with CPS. (August 28, 2015)

Another Black parent, Janae, had poor experiences in neighborhood schools before turning to the charter school. Her son, identified with autism, had attended two turnaround schools in their neighborhood and the frequent turnover of school staff was affecting the services he received. She stated, "I don't have a lotta money-so a private school, Montessori school, that he should haveand I just was being failed by all of these schools out there. The charter was our last resort" (August 27, 2015).

The neoliberal restructuring of the urban space shaped how parents engaged in the politics of desperation in two forms (see Figure 3). First, parents' school selection was tightly connected to the production of urban space through creative destruction. (Theodore \& Brenner, 2002). On the one hand, parents experienced a moment of destruction through the disinvestment in neighborhood schools, which shaped how they experienced or perceived such schools. For instance, Veronica, a Latina mother of a student identified with and emotional dis / ability (ED), stated, Well, the buildings are-they're all not maintained. The different things with the asbestos and the lead paint and all the, you know, not the best. Then just the overcrowding of it too, ... Most of them I think had over 30 kids in a class and then the charter was, they had big classes but they weren't overcrowded to where they had these- They have, like I said, they have a bad rep and right now it's extremely unstable. The Chicago public school, the teachers, they don't have a contract right now, it already expired so right now they're in the process of presenting a budget. They're cutting jobs, they're cutting programs. The first programs that they cut is the special education and they started letting go of many teachers that support our kids. (September 2, 2015) 


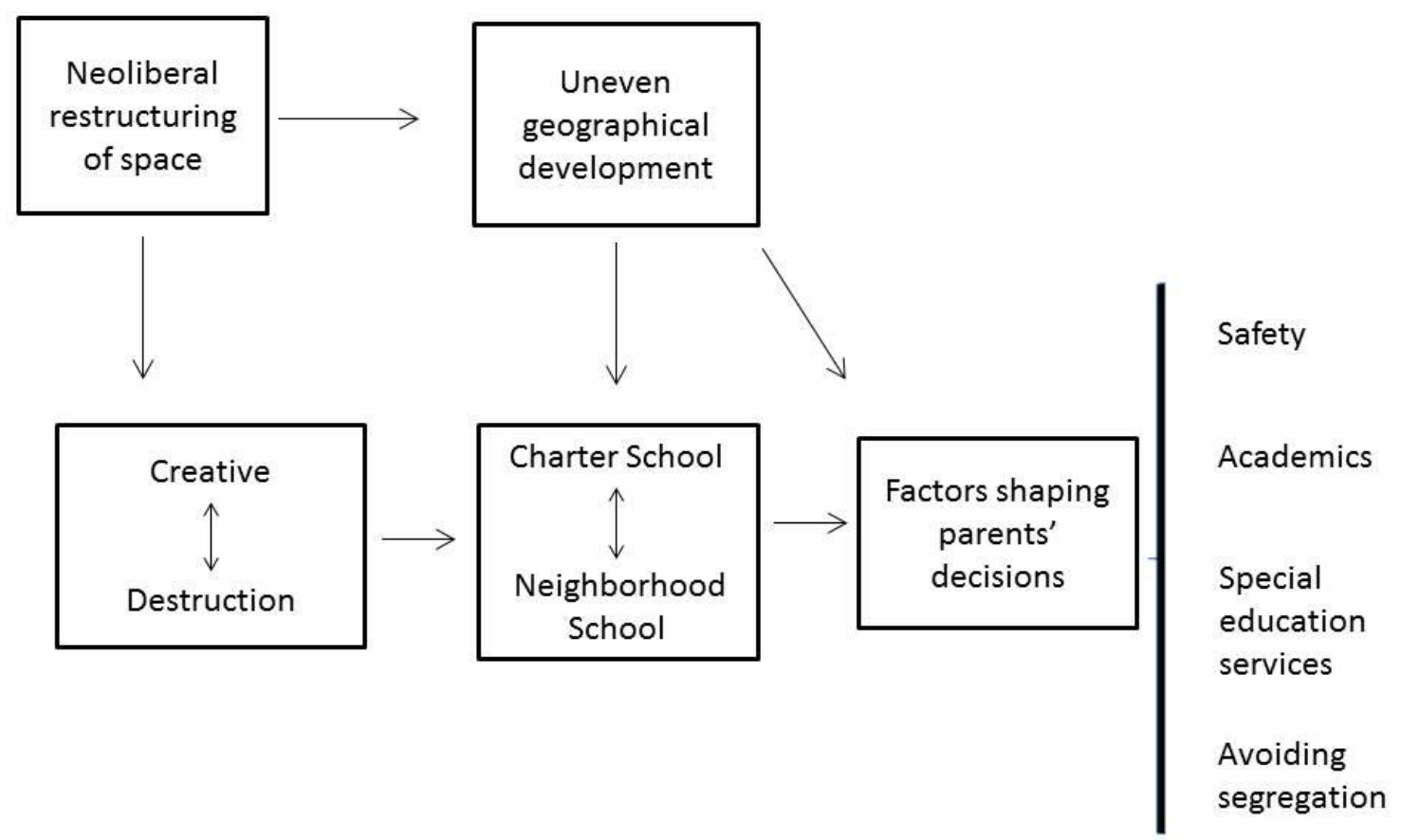

Figure 3. Explanatory model of the politics of desperation.

On the other hand, parents were attracted to charter schools and in a few cases to magnet schools. These schools were the materialization of moments of neoliberal creation of an alluring and well-resourced space. Donna, a Black parent living in an area of extreme poverty, stated, See, these charter schools, some people — a lot of people with money, they be investing in these schools. When I go through the research and I be looking at who they're invest in the schools to where I know if they putting a lot of money in to it, you're gonna get what you're looking for out of it. (October 3, 2015)

For parents of students with dis/abilities, charter schools presented a new option, often unknown but appealing. Stovall (2013) explains, "for many families, in fact, anything is better than what they have traditionally had at their disposal" (p. 42).

Second, the factors that parents considered when enrolling in a school varied across areas of the city associated with the uneven geographical development experienced in the city of Chicago in the last 40 years (i.e., areas of extreme poverty, moderate or serious decline, gentrification, and middle class areas). That is, parents experienced or understood moments of creative destruction differently across the city. In the following sections, we examine how parents' school selections were contextualized in the areas of the city in which they lived, discussing the most salient factors that emerged from each area. 
Table 3

First school attended and factors influencing school decisions across areas of the city

\begin{tabular}{|c|c|c|c|c|c|}
\hline & $\begin{array}{l}\text { Extreme poverty } \\
\qquad(n=7)\end{array}$ & $\begin{array}{l}\text { Decline } \\
(n=10)\end{array}$ & $\begin{array}{l}\text { Gentrification } \\
(n=3)\end{array}$ & $\begin{array}{c}\text { Middle } \\
\text { Class } \\
(n=4)\end{array}$ & $\begin{array}{l}\text { Total } \\
(n=24)\end{array}$ \\
\hline \multicolumn{6}{|l|}{$\begin{array}{l}\text { First school } \\
\text { attended }\end{array}$} \\
\hline Neighborhood & $100 \%(7)$ & $10 \%(1)$ & 0 & $25 \%(1)$ & 9 \\
\hline Magnet & 0 & 0 & $67 \%(2)$ & 0 & 2 \\
\hline Charter & 0 & $90 \%(9)$ & $33 \%(1)$ & $25 \%(1)$ & 11 \\
\hline $\begin{array}{l}\text { Private } \\
\text { Factors } \\
\text { considered in } \\
\text { schooling } \\
\text { decisions }\end{array}$ & 0 & 0 & 0 & $50 \%(2)$ & 2 \\
\hline Safety & $100 \%(7)$ & $90 \%(9)$ & $100 \%(3)$ & 0 & 19 \\
\hline $\begin{array}{l}\text { Special } \\
\text { education } \\
\text { services }\end{array}$ & $86 \%(6)$ & 0 & $33 \%(1)$ & 0 & 7 \\
\hline $\begin{array}{l}\text { Avoiding } \\
\text { Segregation }\end{array}$ & 0 & $10 \%(1)$ & 0 & $75 \%(3)$ & 4 \\
\hline Academics & 0 & $80 \%(8)$ & $33 \%(1)$ & $50 \%(2)$ & 11 \\
\hline
\end{tabular}

\section{Parents Living in Areas of Extreme Poverty}

Areas of extreme poverty experienced high rates of poverty from 1970 to 2010, with little change (NVC, 2014). There was little variation across these communities, which are predominantly Black $(95 \%)$. Household income in these areas ranges from low to high 20 thousands per year. Home values range from $\$ 162$ to $\$ 114$ thousand and only approximately $26 \%$ of the residents are homeowners (NVC, 2014). The poverty rate in these areas is $38 \%$ and single female households with children composed $36 \%$ of the population (NVC, 2014). These areas have a larger proportion of children than any other area of the city $(26 \%)$. Fourteen percent of the residents hold a bachelor's degree, and approximately $24 \%$ of the adults residing in these areas work in management. Approximately $8 \%$ of the children living in these areas attend a private school and in some of these areas most residents live in public housing (NVC, 2014). School closings have significantly affected areas of extreme poverty, accounting for 38\% of all school closings from 2000 to 2013 (Weber et al., 2016). Areas of extreme poverty contain the largest concentration of charter schools $(25 \%)$, but smaller proportions of magnet schools (13\%) (see Figures 1 and 2).

All parents living in areas of extreme poverty started their children in a neighborhood school (See Table 3) and did not move to a charter school until they had an accumulation of poor experiences in the neighborhood school. For parents living in this area, when deciding to move out of the neighborhood school into a charter school, the two most important factors they considered were their experiences with (a) lack of safety and (b) special education services.

Searching for Safety. Seven out of 10 parents who lived in areas of extreme poverty referred to issues of safety as the main reason for moving their children out of the neighborhood school. Parents discussed two safety issues. First, parents referred to issues of gang-related violence 
in the neighborhood, which made the passage to neighborhood schools unsafe. Dominique, a Black Parent of a student identified with ADHD and a learning dis/ability, shared this with us: The neighborhood school, I just didn't care for because that end of the area was rougher than the side I was on. Just like, the selling drugs, or things like that, and I didn't wanna walk through that. ... Gangs, drugs, the shootings, that's rough, and I wouldn't want my child to walk, because the neighborhood high school you have to walk through the Mexicans, and they're being all fighting with knives and stuff like that. It's like a viaduct. It's kind of like, back when I was younger, the Blacks couldn't walk under the viaduct. If you do you got to fight. It didn't matter if you were a boy or girl, this is what they did. You have to make it—it's almost like you gotta fight for your life, if you don't make it back to that viaduct, you may not make it back home at all. ... I didn't want my kids exposed to that. I'm like okay, my older son I had put in the charter school. There were some things I did not like. I knew that the most important thing was safety and education they were gonna get. (September 8, 2015)

Dominique experienced a neighborhood that has been impacted by poverty for over 40 years. The disinvestment in this neighborhood illustrates how Black working class people are deemed disposable by policies and their engineers. In, turn this disposability produces spaces in which searching for safety in schools becomes paramount, and education, as in Dominique's quote, takes a backstage.

Efforts to restructure urban space for capital development also affected parents living in areas of extreme poverty. Kendall, a Black parent, mentioned how her area had gotten worse: I grew up over in Richmond way, the projects that were down the street. Once we moved out, we moved into a different environment which wasn't as bad. However, ever since they closed the projects down, and since the people are scattered now, that's when we began to see a spike in more of the crimes. Since they've closed those down, it's like everybody is like everywhere, that you have certain people coming into certain territories, where the ones who are there are very territorial. Of course, that's the only way I can see those crimes actually going up so high. (October 17, 2015)

By the projects, Kendall is referring to high-rise public housing located in an area south of downtown, an area that has been target for gentrification in the last decade. In this case, efforts to gentrify certain areas and the associated displacement of residents affected adjacent areas and contributed to Kendall's experience of her neighborhood space as an unsafe space, which in turn affected her schooling decisions. In other words, efforts to expand capital and attract middle class professionals sustained and expanded white privilege in the city at the expense of the safety of residents displaced by such efforts.

Second, children of parents living in areas of extreme poverty had personally experienced violence within neighborhood schools before moving to a charter school. Janae had placed her son with autism in a neighborhood school despite her fears:

It's just a neighborhood school, so you got-because of the neighborhood, it's not the best neighborhood, you have a lot of stuff that you don't want - gangs, kids get beat up a lot there, they might get shot, stuff like that. It's just a lot happenin' over there, so I was really scared, but my first instinct was not to put him in a charter school ... He spent a month [at the neighborhood school], and he got into a situation where the kids were beating him up. He would come home scratched up and bit up, and I couldn't take it anymore. It was a month in, and I said —I spoke to 
the teacher, I spoke to the principal, and it just wasn't working' out. I found out that that school had just did a turnaround, so all the staff were new. (August 27, 2015)

Janae's statement makes evident the interactions of the structural power of race and dis/ability. As a Black parent, she was more likely to experience a turnaround school (Weber et al., 2016). This was the second school that Janae's son attended that had been a turnaround. As a student with autism, her son experienced a turnaround school differently than his Black peers without a dis/ability. The lack of consistency in personnel, according to her, had made it difficult to create a consistent plan for her son in both schools. This is not surprising, as students identified with autism struggle with transition and benefit from stable school situations (Boutot \& Myles, 2016). The changing personnel of turnaround schools can create a school environment that does not account for the unique characteristics of students with autism, furthering already established deficit views of these students and making students vulnerable to bullying.

In contrast to their experiences with safety in neighborhood schools, charter schools presented an alluring option, even though most parents had never experienced firsthand those school spaces. Charter schools were perceived by parents as safer than neighborhood schools due to their reputation for tight disciplinary practices. For instance, Dominique explained that at the charter "there has never been a discipline issue. I'm like okay, this is the best environment, and it's safe. I don't have to worry about anyone in the school arguing or fighting with you because there's zero tolerance” (September 8, 2015).

Kendall also referred to lining up as sign of attractive disciplinary spatial practice:

I don't see a lot of those behaviors from other kids, because the area's more controlled. Which is good. Because they set standards as far as this is not tolerated. This is not accepted. As opposed to the neighborhood school, it's like once they get out of the school, just do what you want. Versus when you come to the school, the air that the charter school gives off is this is our school, this is our standard. The kids come there in that sense. They come there, they line up. You don't see them scatter all over the place. (October 17, 2015)

Requiring students to wear uniforms also gave parents a sense of safety. Donna expressed, "I liked how they had their disciplinary setup. It wasn't a school with a bunch of fights. None of that. Dress code. They made sure that boys' shirts were tucked in. Shoes. Their clothes was all together."

(October 3, 2015)

Charter schools portrayed themselves as tightly controlled spaces that gave parents a sense of safety amid the violence they experienced inside and outside the neighborhood school. Parents of students of color with dis/abilities were attracted to such schools as they hoped their children would be less vulnerable to experiencing violence. However, inflexible disciplinary policies often contribute to steering away students with dis/abilities (Losen et al., 2016; Welner \& Howe, 2005). Thus, these disciplinary policies act as gate keepers, separating those who possess the property of 'goodness' from those who don't.

Special education services. Parents living in areas of extreme poverty also had poor experiences with special education services in CPS. These accumulative poor experiences contributed to parents' decisions to move their children to charter schools. For instance, Dominique experienced a poor transition from services provided through early intervention to services provided through her neighborhood school:

No speech therapy, no occupational therapy, no physical therapy. They didn't offer any therapies at all ... I do remember attending a different meeting where we 
discussed the things that they needed, and the whole transition. I told them what my children receive, and they told me that they would receive those things, but they never received them. (September 8, 2015)

Dominique's experienced the structural disadvantages of sending her child to an under resourced school that could not provide her child the services he received before entering school. She experienced the disinvestment in neighborhood schools and in particular the underfunding of special education services.

Dominique's experiences were not unique. Kendall, a Black parent who has a son identified with ADHD and health difficulties, described her son's preschool experience:

At that particular time my son was having a hard time using the washroom. He did that a lot on himself, and he didn't know why. We just thought it was something he was just doing. They suggested that maybe he's just lazy, he's too busy, he doesn't wanna go. Come to find out a couple of years later he actually had a bladder problem, where his bladder had not formed. That was a strike against him. That was a problem with the school. (October 17, 2015)

She also mentioned the lack of support from the school to address her son's behavioral and emotional problems:

I just felt really bad, because I felt I was fighting a system where we're supposed to be helping my son who's having some challenges. He's very smart, very smart. He could not get to that part, because he couldn't get past what we look at now as behavior issues. Maybe doing the typical taking toys from other children, or hitting other children, being possessive, those type of things. I guess his might've been a little bit more accelerated. He was more of a target-it was a negative type of targeting, versus you know what, this kid is really having a hard time. Let's see what we can do to help him. (October 17, 2015)

Kendall's son experience was affected by the intersections of whiteness, smartness, and goodness as properties. The disinvestment in neighborhood schools experienced by Black parents was materialized in the lack of individualized supports for children with dis/abilities. Further, teachers' lack of understanding about dis/ability and prejudice about Black students were reflected in Kendall's narrative in which her son was labeled as lazy or busy, when he had a serious health condition. Black students (and Black people in general) have been historically deemed and punished for being lazy (Connor \& Ferri, 2013). Reflecting this historical trend, Kendall's son was not deemed good or able to perform within the normative parameters of teachers' expectations of what a student supposed to know, do, and be. It is in this context fraught with austerity measures and deficit ideologies that students of color with dis/abilities are expected to learn and thrive, a characteristic of selective inclusionism.

In contrast to their experiences in neighborhood schools, charter schools gave parents the possibility of individualized attention. Janae, who had struggled getting her son's individual needs met in neighborhood schools, described the promise of small class size at the charter:

One thing that stuck out to me, they said to me there are going to be 13 or 14 kids in each classroom with two teachers. I thought, "I hit the jackpot. Here we go. This is it. I love it." This is why I signed him up, because I felt like my child needs so much extra attention, and this would be awesome for him. (August 27, 2015) 
Donna said,

I always pay attention to the settings as well, because I'd rather for them to be in a small setting than a large setting. Because if you're a small setting, you can't fall into the cracks. If you in a large setting, then you got it to where the teacher has to pay attention to everybody in the classroom. For a child in there that need-has some needs that need to be met, they not gonna get it. The charter school was a small setting. They didn't have no more than probably 10 to maybe 12. (October 3, 2015)

The allure of charter schools was based on their small teacher-student ratio. Interestingly, parents living in areas of extreme poverty did not talk about the special education services in charter schools. Amid the disinvestment and marginalization experienced in neighborhood schools, small student-teacher ratio was perceived by parents living in areas of extreme poverty as a sign of resources and a way to attend more closely to the individual needs of their children.

\section{Parents Living in Areas of Serious Economic Decline}

Areas that experienced serious economic decline from 1970 to 2010 are located in Chicago's West and far South Sides. These communities are largely Black and Latinx $(66 \%$ and $28 \%$, respectively). The percentage of students attending private schools is the second lowest in all Chicago at $9 \%$ (NVC, 2014). Poverty rates are approximately $24 \%$ and the households headed by single females constitute $20 \%$ of all households in these areas (NVC, 2014). Though household values are one of the lowest in the city, homeownership rates are above the city average in this area. Incomes vary from low $\$ 50$ to high 30 thousands. Only 15\% of adults hold a bachelors' degree and approximately $23 \%$ hold a managerial job (NVC, 2014). School closings in these areas have been prominent as well as the opening of charter schools. These areas contain $18 \%$ of all school closings and $20 \%$ of all charters in the city, while only $13 \%$ of all magnet schools (See figures 1 and 2).

Parents living in areas of serious economic decline enrolled their children in a charter school from kindergarten on. Only one of these 10 parents sent their child to a neighborhood school in kindergarten: Therese. Therese was a single Black mother who experienced housing instability throughout her child's educational trajectory. She started her son in a neighborhood school while living with her brother in an area of poverty, but later, when she was able to "get on her feet," she moved to an area of serious decline and opted for a charter school.

Parents living in areas of economic decline never sent their children to a neighborhood school due to two main factors (a) safety and (b) academics in the neighborhood school.

Safety: Neighborhoods and Symbols. Nine of the 10 parents living in areas of serious decline described issues of safety in the neighborhood as their primary reason to never attend a neighborhood school. Thus, an unsafe neighborhood was the single most important factor shaping parents' decision to avoid a neighborhood school. For instance, Shanell, a Black parent of a student with autism, linked her concern of safety at the neighborhood school with broader neighborhood safety issues:

The neighborhood school was in Mount Franklin. Somewhere over there on McGuire street, over that direction. It wasn't acceptable for me [...] It's the hood. Even before I moved over here is considered, pardon my language, the hoe stroll. Prostitution. Prostitutes walk, up and down, there's a motel right here on this corner. They take johns. That's this neighborhood. There's a lot of drug activity. To me, it was in too close proximity, especially when you're talking about a special needs child who does not talk. (August 28, 2015) 
Shanell lived in an area that had declined over time due to a lack of economic investment. The area had deteriorated, creating areas in which crime had flourished. As she stated, this took a particular significance for her when thinking about her child with autism. Here, a student with a dis/ability experiences urban space restructuring qualitatively differently than his white peers with dis/abilities who were unaffected by decades of neighborhood disinvestment and live in safer areas of the city. In addition, his experience differs from his Black peers without dis/abilities as having a dis/ability can make a student more vulnerable to be the victim of bullying and other forms of violence.

Wendi, a Latina mother of a student identified with ED, is another key example of how urban space restructuring contributed to parents' engagement with the politics of desperation. Wendi stated,

Latinos have moved over here drastically. The gangs, they're moving from everywhere, the North Side particularly. They're bringing their gangs with them. When they migrate, everything comes with them. They're bringing drama [...] That concerns me 'cause I have a 21 -year-old and I have a 14-year-old boy. These are two boys. I don't want anybody putting their hands on my child. You gotta be careful. Living over here, your best bet is to put 'em in the charter school. There's no winning. You got the neighborhood school down the street. I live here. Before I put my kids there, they're gonna be at the charter eating whatever they're eating. Even though I'm not happy, I'd rather let them be at the charter. I do it for safety reasons. Educationally, they're not learning that much there either. (August 26, 2015)

Wendi lived in an area of economic decline that borders gentrified areas to the north and the east. All these areas have been traditional areas of Latino working class settlement. Once gentrification expanded from east to west in the city, many residents moved further west to where Wendi lived. Similar to what Kendall describes above, gentrification had effects on parents' perceptions of safety in areas of serious decline, which in turn shaped their schooling decisions.

Gentrification has also affected Wendi's family in another way, as she stated, Oh, but of course. Gentrification is dominant over there. You have to have money to stay over there. At one point, 'cause I used to live in Garden Square Apartments, across the street, it was a big building. That building was a rental building. Now it's all condos. You walk around the neighborhood, you see mostly caucasian palefaces more than you do people of color, which is the typical Dominican, Puerto Rican, Cuban, Panamanian that they'd look Black, but they're Latino. Now the rent is high. You can't live over there. You want a three bedroom, you have to have at least twothousand-plus dollars, $\$ 2,500$ to live over there. That's what it is. They're pushing us further and further west. (August 26, 2015)

Wendi had previously lived in a gentrified area with her mother. The "renewal" of the city through gentrification has not benefited Wendi. Due to high rents she moved further west where she felt the neighborhood schools were not safe and therefore felt compelled to send her children to a charter school. The process of creative destruction associated with the area where she lived created poor alternatives - either an unsafe neighborhood school or the perceived safety of a charter school. Neither of these options, according to Wendi, offered rich opportunities to learn. Wendi engaged with the politics of desperation in which safety becomes a primary factor; she 'chose' around the structured opportunities offered to her.

In contrast to parents living in areas of extreme poverty who attended neighborhood schools, parents living in areas of serious decline perceived neighborhood schools through images and symbols rather than by firsthand experience with the schools. The most recurrent of the 
symbols that shaped parents' working knowledge of the neighborhood school was the image of other students and families attending the school. Sandra, a Black parent, recalled her impression of the children attending the neighborhood school:

I went over there [neighborhood school] and the conversations I heard and the sights that I seen right off the bat you know I wouldn't--cursing, sagging pants. They were cursing out the security guard. It was total chaos and I knew I was not going to leave and even though they were my foster kids, my adopted kids, I said they my kids. I flew out of there. They said we don't allow sagging and all I was looking at was sagging. (September 10, 2015)

These images of other students were significant to parents of students of color with dis/abilities, as parents were afraid that their children were more vulnerable to experiencing harassment and violence at school. They were also concerned that their child would be singled out or identified as dis/abled by other students. Shanell shared with us, "The kids [at the school] are smart, but they're bad as hell. Bullying is always a concern. Is he gonna be in an environment where he's gonna be able to be identified, things like that?" (August 28, 2015). Shannell perceived children in the neighborhood school as "bad as hell" but smart. As Broderick and Leonardo (2016) remind us, this is a powerful combination, "Without the qualification of goodness (for example, willingness to listen, to demonstrate docility, compliance), smartness become something uncontrollable and potentially dangerous" (p. 58). Goodness validates smartness; without possessing goodness, one can be 'too smart for their own good' or a 'criminal mastermind' (Broderick \& Leonardo, 2016).

Interestingly, while the school that Shanell is referring to is composed almost $100 \%$ of Black students, so was the charter school in which she enrolled her child. So, why were some Black students perceived as signs of unsafety while others were not? We discuss later one explanation when examining the disciplinary practices of charter schools. The other explanation has to do with other set of symbols that contributed to pathologize Black students attending neighborhood schools. Contributing to a negative perception of Black students were other neighborhood and school symbols, which included metal detectors, empty bottles in the school vicinity, security guards, unkempt facilities, police presence, drug dealers hanging out in the school block, and drug searches in schools. For instance, Keisha noted, "I go past public schools or have friends that went to 'em and they fight and they had a police outside" (September 25, 2015). Simone commented that she had learned from, "Other people's experiences. Just like not being safe at the school. You know, I hear about the metal detectors and bullying" (September 4, 2015). Rosanna also stated,

The amount of metal detectors, of security that was there, it was just outrageous. I didn't want to expose her to that type of stuff. This was kindergarten and first grade. It was ridiculous, the flyers that they sent home from the CPS schools--'cause her friends went to CPS. They go, "Oh, well, look what I found," and somehow their mail, their little flyers would end up at my doorstep: "Oh, yeah, so we conducted a drug search today or a gun search today.” (September 11, 2015)

Ironically, CPS efforts to make schools safe (e.g., metal detectors and security presence) signaled to parents living in areas of serious decline that the schools were not safe. Black and Latinx parents of students with dis/abilities read these signs of unsafety and did not want their children to attend such spaces nor be around 'those students'. Thus, efforts to keep students safe contributed to pathologizing the schools and the youth attending them. In turn, this contributed to parents' decisions to move to charter schools.

In this context, parents living in areas of serious decline perceived charter schools as safe spaces. Simone explained, 
When I first came what impressed me, in the hallway I heard not one peep, not one sound. Most times you come to school you hear all this ruckus and things going on. Not one sound. No kid was out of line, nobody was pushing or shoving. I was like what did you do to these kids? Are they drugged or something? They're like walking in line like military style. I don't mean like that all stiff, but they were very well behaved. I said wow, I like that type of discipline. I don't know what you did to get them like that, but I don't hear anything. I can literally drop a pin and hear it. I just was very impressed with that. (September 4, 2015)

Here we see the other reason for perceiving Black students in charter schools not as threatening as those in neighborhood schools. The practices of regulating bodies through straight lines and silence were taken as a symbol of safety by parents. Parents' perception of charter schools as a safe space was informed by the ideological work of goodness. As Broderick and Leonardo (2016) explains, Black students who cannot claim goodness are exposed to tighter surveillance and control and therefore more likely to receive some sort of punishment. Their behavior becomes a matter of individual pathology that is increasingly criminalized (Ferguson, 2001). Parents living in areas of serious decline were attracted to such disciplinary control that made Black students not a threat to school safety.

Further, in contrast to the student and family composition of neighborhood schools, charter schools offered to parents the promise of a different student body in a space away from the neighborhood youth. For instance, Therese stated:

The reason why I put him in the charter school is [at the charter] they comin' from different neighborhoods and they got different opinions and different upbringings and stuff like that. You're not with-you got people in the neighborhood. You might got three friends that always beat up on you. Because they close and you don't come outside. Every time you come outside you gotta duck and dodge. I remember that boy that used to beat him up. Now I'm at a charter school. We're not exactly in the area so if you want him you gotta get on that bus. You gotta come look for him or you gotta take your time to come look for him. (August 18, 2015)

Charter school enrollment based in a lottery system contributed to parents' perception of safety. That is, charter schools drew students from other neighborhoods and sometimes brought their child into a different neighborhood for school, which was perceived by parents as a sign of safety. Therefore, for Black parents of students with dis/abilities living in areas of serious decline, Black students could be a sign of safety if they were controlled by tight and punitive disciplinary practices or if they were from outside the neighborhood.

It is interesting that for some parents disciplinary rigor was even thought to be a form of therapeutic practice for those students with behavioral difficulties. Angela, a Black mother, stated, I was going to put her at the public school, the CPS school over here. After she was diagnosed, I felt that she needed to be some place a little bit more structured. It's the school that's in the neighborhood, but I, you know-that's where her brother goes, but I felt she needed something a little bit more structured. Where it was more confined, I guess. See, how can I describe it? I guess where the school was more aggressive as far as discipline. (August 16, 2015)

Sandra's statements support those of Angela:

I got word on charter schools, charter schools they have a disciplinary policy I thought would be more conducive to my kids [since they have] behavior issues. I 
thought they needed something a little firmer, almost like a militant-type situation. (September 10, 2015)

Charter schools were perceived by Black and Latinx parents of students with dis/abilities as places in where students could get their behavior under control. In other words, charter schools were perceived as spaces where students with emotional and behavioral difficulties could become 'good boys' and obtain goodness as property, if they were shape up by the disciplinary policies of charters schools.

Academics. Academics were the second most prominent factor affecting the school decisions of parents living in areas of serious decline. Eighty percent of parents living in areas of serious decline discussed their perception of academics in neighborhood schools. Some parents' perceptions, like Keisha's, were informed by her own experience as a student in a neighborhood school. Referring to her peers in CPS this Black mother stated,

They could not read basic words like "there" or "anything," "sometimes"-first- and second-grade words. They're sitting there sounding out words in eighth grade. I'm like, "Oh, I can't have my kids..." Really, in eighth grade, you're going to high school, you're almost an adult and you can't read. I think they just pushed the kids along. (September 25, 2015)

According to parents, neighborhood schools let students move to the next grade regardless of whether they learned grade-level content or not.

In addition, the labels given to the school by the district based on academic outcome data shaped parents' perceptions of the neighborhood school as that of poor academic instruction. Shanell, for instance, described the research she conducted online:

You see the neighborhood I live in. Neighborhood schools don't have the best of anything. First of all, I've never been opposed to a neighborhood school. What I want is a school that's gonna be able to meet his needs, but when you're doing research, none of those schools come up. If you go on GreatSchools.org and you look in schools in your neighborhood, and they have a rating of one or three. You go to the CPS site and you're looking at how they-how their test scores are against everyone else, and it's 20th percentile, 15th percentile. (August 28, 2015)

Rosanna, a Latinx parent living in area of serious decline, stated, "If I were to go online and look at it, you guys have really low test scores for the area, and I don't need you preparing my kid for a test that you guys - that she's more than likely gonna fall way below average" (September 11, 2015). Test scores published in online websites reinforced the ideological work of smartness. They achieved a symbolic work that pathologized predominantly Black schools and their students, creating a hierarchy of achievement that justified closing or turning around neighborhood schools in Black neighborhoods. These school actions represent a moment of neoliberal destruction that profits from a racialized discourse of failure, which contributes to the historical construction of Black and Latinx students as deficient (Lipman, 2002). Black and Latinx parents of students with dis/abilities draw from such racialized discourses to decide to never attend a neighborhood school.

In contrast, charter schools had a reputation for academic rigor. First, charters promoted themselves as a straight path to college. Therese, a Black parent, referred to the academic reputation of the charter school, "Then you see it on TV. They got $100 \%$ college graduation. Then you had to go to the career night or something" (August 18, 2015). Barbara used similar expressions explaining her interest in the charter: "Because I had heard that the charter school has the $100 \%$ college rate" 
(August 22, 2015). This was not exclusively the concern of the parents whose children with dis/abilities were in high school. Shanell, whose child was in kindergarten, was impressed with the academic focus of the charter:

The whole charter network, their entire charter surrounds pre-K to college. When you look at their history, they pretty much-their charter's surrounding intense academics, but getting everybody into college. Everybody. Within the last, I think, four or five years, they've had $100 \%$ college enrollment for their kids. $100 \%$. I think the years before that where it wasn't $100 \%$, it was $98 \%$ and $99 \%$. That appealed to me. (August 28, 2015)

The discourses deployed by charter schools and their marketing mechanisms contributed to their reputation for academic success. Charter schools deliberately market themselves as places of strict academics and as a gateway to college. For instance, one of the brochures of a charter school stated: $100 \%$ of our graduates have been admitted to 4 -year colleges. These colleges include prestigious institutions like Cornell University, Dartmouth College, Georgetown University, Morehouse College, Northwestern University, The University of Illinois, The University of Rochester and The University of Virginia. In addition to these admissions, graduates have amassed millions of dollars in college scholarships. (Charter brochure \# 49)

It is interesting to note that parents of students with dis/abilities living in areas of serious decline were attracted to the charter's promises of college access, which contributes to forming independent contributors to the economy. Yet, the charter space is selective in their inclusionism. These rates to access to college are based on the students who ultimately graduate from the charter and ignore those students who have been weeded out through the school years and students with dis/abilities who may finish their senior year but do not officially graduate from the charter school but transfer to other CPS programs until age 21. Further, many of the parents we interviewed experienced conflict with the charter schools as the extensive homework and academic work, coupled little support from qualified personnel, contributed to steering them away from the schcool.

Second, giving extensive homework was an important practice contributing to the charter school reputation as academically rigorous. Comments from a Black mother named Aisha supported this point: "The public schools are, okay, well, if you get homework, you get homework. With the charter schools, you're coming home with homework every day, even on a Friday. You have a project due maybe, out of the week, twice, and I love that" (September 3, 2015). Therese, a Black parent, also noted,

When I went in I liked the school. They told me the curriculum. It was moving from class to class. It had where if you miss your homework you had to do homework detention, which was great. If he missed class, when he would do homework detention. He would have to be in detention and do the homework that he missed, which was helpful to me. (August 18, 2015)

In sum, parents living in areas of serious economic decline never attended a neighborhood school and enrolled their children in a charter school in kindergarten. Similar to parents living in areas of extreme poverty, parents living in areas of serious decline mentioned safety as the main factor for their schooling decisions. However, in contrast to parents living in areas of extreme poverty, their children did not directly experience harassment or violence in the neighborhood school. Instead, their perceptions of safety came from the symbols they had seen in such schools, including the 
parents and children in neighborhood schools and safety measures such as metal detectors and security guards. In addition, parents' perception of safety in the neighborhood was related to the restructuring of urban space, as they mentioned how gentrification and areas of disinvestment that have seen an increase in crime had shaped their schooling decisions. Finally, parents also referred to the academic reputation of both neighborhood and charter schools as a critical factor in their decision-making.

\section{Parents Living in Areas of Gentrification}

Concentrated areas of gentrification are located in the near North, South, and West sides of the city, providing its residents easy access to downtown and the lakefront (see Figure 2). Since the 1970s, these areas have experienced large economic gains, though factors and timing affecting the economic growth in each of these communities varied (NVC, 2014). Economic growth in the near south and west side was largely due to the boom of high end construction in the late 1990s and 2000s, while areas in the north of the city developed due to the upgrading that occurred in the 1980s. Residents in these areas are largely White (64\%), while Latinx and Black residents account for $14 \%$ of the population in these areas. The percentage of children in these areas is $9 \%$ (NVC, 2014). Seventy percent of the residents hold a bachelor's degree and 61\% work in management occupations (NVC, 2014). Poverty is low at $9 \%$ and the percentage of single female-headed households is $8 \%$ (NVC, 2014). The average income is $\$ 115,972$ and home values vary from the low $\$ 300$ s to mid$\$ 400$ thousands. Approximately $40 \%$ of the children living in these areas attend private schools (NVC, 2014).

When asked a broad question about the area where they live, parents shared stories related to the gentrification of these areas. Jada, a Black parent who lived in a gentrified area in the near South of the city, shared with us,

They built the Walmart over there. They put another market over there. Nothing racial, but we have saw-start to see more Caucasians, Asians, Mexicans this way because I grew up over here, like three blocks down. I grew up three blocks down. When I was a kid, there was no-it was predominantly African-American but as things start changing, the neighborhood start changing, the diversity start changing [...]Two days ago, I was in the back. I saw a white man walking' through the alley. I guess he lives up the street down there. We are not going to bother him, we're just looking like, "Okay, they're here; they're human. (September 9, 2015)

Lizbeth, a Latinx parent, expressed similar stories about her neighborhood, We moved here in 1979, and we couldn't sit outside to play because there were always drive-bys and shootings and gangbangers. Before the viaduct became trendy and became the 606 elevated trail, that was the dividing line for two gangs. These were Kings, and those were something else. I can't remember what it was. This was the dividing line. These guys were always running over there and shooting it up. (September 19, 2015)

Lizbeth is referring to an elevated trail that the city inaugurated in 2013 as a way to supporting the gentrification occurring in a group of neighborhoods located in the Northwest side of the city. Though the trail may have benefited property owners in the area, the large majority of residents $(65 \%)$ are renters who run the risk of being priced out of the area, as illustrated in the quote from Wendi in a prior section. explained,

Rochelle, a black parent who lived in a gentrified area in the west close to a major University, 
I was in the Public Homes right there on Galbert and McKenzie. They're all gone. It's nothing but land there. I see how the neighborhood has evolved. I see whereas the train line didn't stop nowhere through there. It stops now. They have two stops actually, and I'm like, wow, I can-[gasp], they got this here and they got that here? I know it's making it convenient for the doctors and the lawyers (December 15, 2015)

Rochelle's quote, as well as the quotes from other parents living in areas of gentrification, reflects the disposability of and lack of investment in Black and Latinx working class communities. It is not until the neighborhood becomes primed for gentrification that stores are added, old train tracks become elevated trails, and train stops are created. Working class Latino and Black communities are not perceived as worth of investment until their interest converges with those of real estate developers and more affluent families. Bell (1980) called this interest convergence, the idea that white mainstream society will support the interests of racial minorities as far as they convergence with their interests. In Chicago, interest convergence gains further complexity as gentrifying families are not only White but also middle class Black and Latinx residents (Stovall, 2013).

Working class Black and Latinx families that can afford to stay in gentrifying areas have the consolation prize in form of school options such as magnet schools and charter schools. Despite these changes in their neighborhoods, two parents living in areas of gentrification initially enrolled their children in magnet schools, while a third parent applied to two magnet academies and ended up at a charter school. The two parents who enrolled their children in magnet schools decided to move to charter schools once their children transitioned to high school. Parents' preference for magnet schools in this area can be attributed to the fact that those areas of gentrification contain the largest number of magnet schools of any other area of the city; $40 \%$ of all magnet schools are located in areas of gentrification. In addition, these areas have experienced a significant number of school closings (22\%) and have high concentrations of charter schools (17\%), but not as high as areas of extreme poverty or serious decline. Safety and academics were the two main factors that parents living in areas of gentrification considered when choosing to send their children to magnet and charter schools.

Safety. Despite gentrification, parents living in these areas did not trust the safety of the neighborhood schools. Safety was the main reason for parents' choices to send their children to a magnet or charter school. For instance, Lizbeth described her concerns:

I knew that the neighborhood still wasn't the place for Jesus to go to. Because of the gang problem. I didn't even need to know the school because if there's a gang problem there, then he didn't need to go there. Plus, even though that is his neighborhood school, if they would have found out where he lived, they would have thought he was from a rival gang. The school line doesn't follow your neighborhood line. What it follows is what gang is in that school. If that school is in an opposing gang's neighborhood, then even though it's your school, you can't go there. With his disability it wouldn't have gone well [...] I felt like if he went to one of those schools, I don't think he would have been able to survive that. (September 19, 2015)

Lizbeth was concerned about the students attending the neighborhood school and their gang affiliation. She was afraid that her son, who was diagnosed with ADHD, would have been unsafe in neighborhood schools. Ironically, Lizbeth's son experienced bullying in the magnet school in $6^{\text {th }}$ grade,

One day, I pull up to pick him up, and I see he's on the ground, and somebody's kicking him. I run up to him and I'm like, "What are you doing?" Jesus is just sitting 
there. I pick him up off the floor and I said, "Why are you letting him kick you?" He's like, "Because he said if I let him kick me, he would be my friend." At this point, he's been labeled a dummy at school because they're pulling him out for services, and he goes to the dummy class. He figured that getting beat up was better than not having a friend, and maybe if he had this friend, he wouldn't be the dummy anymore. (September 19, 2015)

It took significant efforts from Lizbeth to force the school to address the issue, and when her son graduated from the magnet school in $8^{\text {th }}$ grade she decided to go to a charter high school due to her negative experiences in the magnet school and her serious concerns about gang activity in the local high school. The other school option for Lizbeth would have been a selective enrollment high school, but her son with a dis/ability would not have qualified for such school. Thus, moments of neoliberal creative destruction leaves Black and Latinx students with dis/abilities with shrinking school options. While the disinvestment in neighborhood schools and their history of gang violence made these schools unsafe spaces, the creation of new school options through interest convergence (i.e., magnet schools and selective enrollment) did not offer a viable alternative, leaving parents of students with dis/abilities with the one remaining and unknown option: the charter school.

Academics. The level of academics was an important factor for parents living in areas of gentrification. Jada stated,

I believe that if you can find a better education somewhere else outta your neighborhood school, it's always we got to go for the best. Why have mediocre education when you can get some of the best education? I don't believe that he has the better education. I don't believe neighborhood schools are going to teach our children the best. (September 9, 2015)

Charter schools, in contrast, offered the promises of college access, as Jada stated: City Prep—what did I like about City Prep? One hundred percent of their boys go to college. Every boy in that school goes to college. There's no ifs, ands, or buts about it. Every year all their kids get accepted to college (September 9, 2015).

Lizbeth made similar statements,

I will say one of the best things that these charter schools have is a team that helps the children put all their information together and get them out to colleges. Not only that, but when they go off to college-next year, when he goes off to college and he needs help, they can come back to the charter school, and they'll help him fill out that FAFSA all over again. I thought that was awesome. (September 19, 2015)

In sum, despite the changes in their neighborhood due to gentrification, parents' concerns about the neighborhood school were similar to those of parents living in areas of serious decline: safety and academics. However, parents living in areas of gentrification had more magnet options than any other parents in the city, and opted for these schools until their children were transitioned to high school. At this point in time, a selective enrollment high school may not have been an option for their child with a dis/ability. It was then that these parents opted for a charter school.

\section{Parents Living in Middle Class Areas}

Middle class areas showed economic stability from 1970 to 2010 and they clustered in the far north and Southwest sides of Chicago, with some isolated areas in the South side of the City by the 
University of Chicago. These communities tend to be 50\% White, 20\% Hispanic, and 24\% Black (NVC, 2014). Residents in these areas are more likely to be homeowners that in any other area of the city and their income ranges from low $\$ 50$ to high $\$ 80$ thousand a year (NVC, 2014). Thirty-one percent of children living in these areas attend private schools. The percentage of the female-headed households is $10 \%$ and the poverty rate is $9 \%$. Only 3\% of all Chicago school closings took place in middle class areas. These areas contain $4 \%$ of all charter campuses, and $14 \%$ of all magnet schools.

In our study, Black and Latinx parents living in middle class areas were more likely to enroll their children in a private school than parents in other areas, but then due to cost or lack of special education services in private schools, they moved their child to a charter school. With one exception, the main factor shaping these parents' decision not to attend a neighborhood school was the school district's tendency to segregate students with dis/abilities in separate classrooms.

Avoiding segregation. Black and Latinx parents living in middle class areas were concerned about placing their child in a segregated classroom. Rebecca, a Black parent, shared with us her ongoing struggles to place her son with autism in an inclusive setting. Starting in preschool through kindergarten, CPS wanted to send her child to a segregated autism cluster program. Cluster programs are self-contained classrooms located in various neighborhood schools that provide services for students with dis/abilities. The IEP team may decide to place a child in a cluster program in a neighborhood school even if it is not the neighborhood school serving the child's home area. Rebecca described her struggles with her son's teacher:

When he was supposed to go for their kindergarten class, which means he was supposed have a regular teacher then maybe get pulled out for resources or something, the regular teacher didn't want him in class. She just didn't want to deal with it. She thought he just was going to be too difficult, and at that time he didn't have paraprofessional because he was in a special ed class. It was like he would have to be able to handle being in the regular class without any assistance. She had no interest in him going to the class and we tried that year and we started—she had him with a security guard. She wasn't very accepting. (August 25, 2015)

Rebecca's son was placed in a separate classroom due to lack of teacher aides and the teachers' ableist attitudes and beliefs about her son with a dis/ability. Her kindergarten son could not claim goodness as property and was perceived as in need of containment and close control either through a separated classroom or with a security guard in the general education classroom. Understandably, Rebecca tried to take her son out of this situation, but all her attempts met with resistance from the district:

At that point I ended up trying to transfer him to my neighborhood school and they wouldn't accept him because he was a transfer student and blah, blah, blah, blah, blah [...] I ended up homeschooling for a year. (August 25, 2015)

When the time came for her son to start first grade, she attended another IEP meeting with the hope that he would be placed in an inclusive setting:

It was time for his placement in first grade. They wanted to put him in an autism concentrated classroom. I didn't agree. He didn't really do anything wrong except for being who he was, and they just felt that they couldn't teach him there. My whole argument on it was the fact that they could. His differences weren't something that could not be accommodated within that classroom, within the school. They said that he needs very specialized care. He needs to be on this autism cluster program.

(August 25, 2015) 
After another failed attempt, Rebecca told us: "I was done. I was done with public schools." Rebecca struggled with special education placement throughout her son's educational trajectory. Even once her child was attending the charter school, she experienced segregation and steering away practices_-a story examined in a different article (Waitoller, 2017). Sarah, a Black mother of a student identified with ADHD, experienced a similar story:

I noticed my son's dis/ability—well, when it came up and we did the other intervention program, right. Going to the other intervention program, we went to our neighborhood school. That's when we had the first IEP meeting. He must have been, maybe three and a half? When we had that meeting - so it was everybody. Just very, very overwhelming and confusing. That time, when we talked, he was supposed to go to kindergarten there in the regular. After we had finished everything, and I was just waiting to talk to the social worker, she went and saw the principal. Then she came back and says, "Oh, the principal says that he should be in a self-contained special education classroom." For me, that didn't make sense. I was like, "How he does he end up-he has learning-like, speech and behavior. It's mainly speech. How do you put a child with speech with other kids with other multiple dis/abilities in kindergarten?" The most restricting thing, it was not part of what we had discussed inside of the IEP. That's when we decided like, "I can't do that." That's how we ended up in the charter school... I'm so tormented about the neighborhood school that was going to put him in a self-contained special-ed classroom. For me, that was-and we know it's like "the warehousing of kids." (September 30, 2015)

When transition from early intervention services to kindergarten, CPS wanted to place Sarah's son in a segregated classroom. Once she learned in the IEP meeting that her son would be segregated, she decided to move him to a charter school before he started kindergarten

Rebecca's and Sarah's experiences reflect selective inclusionism and its rigidity. In order to become integrable to the general education classroom, their children needed to 'overcome their dis/ability' amid the lack of resources in neighborhood schools, as evidenced in the lack of paraprofessionals or aides for students, and ableist assumptions that position dis/ability as something to be contained and controlled. These assumptions take as normal the exclusionary design of general education classrooms and leave it unchanged, benefitting those deemed integrable. Further, the experiences of Rebecca's and Sarah's experiences reflect the CPS troubled history of segregating students of color with dis/abilities in separate classrooms. Living at the intersections of race and dis/ability, Rebecca's, Sarah's, and their children's experiences were qualitatively different from those of Black and Latinx families of students without dis/ability living in areas of middle class, as these latter ones do not experience segregation in their neighborhood school.

In contrast, charter schools have a reputation for maintaining small student-teacher ratios within the general education classroom. For instance, Sarah commented, "The charter school was good. It was very small classes, very homey". Rebecca also referred to smaller classrooms: "Yeah, it's a charter school because it's a smaller classroom, which was important to me" (August 25). Aisha went straight from a private school to a charter school as her son identified with ADHD transitioned from preschool to kindergarten. When asked why she decided in charter school, she explained,

[T] he classrooms are smaller. In the charter schools, they are smaller. It's 24 kids to a teacher, with the aides in the classroom helping. In the public schools, they don't get that. It's, what, 30, 35 kids to a teacher. If I had put him back in the public school, Elijah would've got lost, and I can't—-because what they do with the public 
schools - and I've witnessed it. I've heard the stories. They don't take them out by the group. He would have just got thrown in a special education class with just kindergartners, first graders, second graders, third graders. With the charter school, he's in a general education, and there's aides in there to aid him, so he's not feeling like, "Oh, okay. I'm just in this room. I'm not learning." That's why I chose a charter school. It is much better. (September 3, 2015)

Similar to Sarah's comments about CPS "warehousing" children with dis/abilities, Aisha refers to CPS's reputation for "throwing" children with dis/abilities in rooms that offer few learning opportunities. This was her main reason to never enroll her child in a neighborhood school. Charter schools offered smaller schools and teacher-student ratios, which meant to parents that their children would have more support to be included in the general education classroom.

\section{Discussion}

The purpose of this paper was to examine how Black and Latinx parents decide to enroll their child with a dis/ability in a charter school. We were interested in the relationship between such decisions and the neoliberal restructuring of urban education space. We found that Black and Latinx parents of students with dis/abilities engage in the politics of desperation (Stovall, 2003). That is, amid the historical disinvestment and destabilization of Black and Latinx neighborhoods and neighborhood schools, coupled with the district's history of ableist practices, parents are enticed by the newness and promises of charter schools. Further, how Black and Latinx parents of students with dis/ability engaged with the politics of desperation varied according to the areas of the city in which parents lived (i.e., areas of extreme poverty, serious decline, gentrification, and middle class areas). Thus, the present study contributes to research on school choice defying simplistic models that privilege an individual and rational view of decision-making (e.g., Pedroni, 2007). Our findings indicate that a robust understanding of how parents make school selections needs to account for the intersections of race, dis/ability, and urban spatial restructuring.

Our findings demonstrate how Black and Latinx families of students with dis/abilities engaged with school choice in ways that are qualitatively different from those of their White counterparts as well as those of Black and Latinx families of students without dis/abilities. White parents of students with dis/abilities may experience the austerity measures and the segregationist practices of the district, and their children may be marginalized by the ideological work of smartness and goodness as property (Broderick \& Leonardo, 2016). Yet, they tend to be unaffected by the closing of neighborhood schools and the expansion of charter schools as we discussed in the introduction of the paper (see Figures 1 and 2). They possess whiteness as property and enjoy the benefits of living in city areas that benefit from uneven geographical development. Black and Latinx parents of students with dis/abilities were doubly impacted by such spatial restructuring that protected whiteness as property. For instance, they were affected in particular ways by the historical disinvestment experienced in their neighborhoods and the related safety issues; according to their parents, having a dis/ability makes them more vulnerable to bullying.

Further, the legal and historical aspects of race and dis/ability worked together and separately to marginalize Black and Latinx families of students with dis/abilities (Annamma et al., 2013). On the one hand, education policy in Chicago and its relationship with the neoliberal restructuring of urban space is grounded in Chicago's racialized history (Lipman, 2003). Moments of creative destruction (Theodore \& Brenner, 2002) result in polices that both (a) systematically disinvest in, pathologize, and prescribe surveillance and punishment for Black and Latinx youth and

(b) expand the development of charter schools and their reputation of high academic achievement 
and zero tolerance measures (Lipman, 2003). These legally sanctioned efforts to discipline Black and Latinx youth serve to make the city feel "safe" again, creating areas of gentrification that attract middle class professionals, most of whom are White, and thus contributing to the maintenance of whiteness. On the other hand, the legal provision of the least restrictive environment that does not guarantee inclusion in the general education classroom along with legally sanctioned budget cuts to special education result in poor services that leave Black and Latinx parents of students with dis/abilities with few school options. The legal histories of race and dis/ability work together to push Black and Latinx parents of students with dis/abilities to engage with the politics of desperation.

Urban space restructuring adds another layer of complexity to the intersecting forms of exclusion experienced by Black and Latinx students with dis/abilities. Socially produced space is a driving force in shaping Black and Latinx parents' engagement with the politics of desperation. Black and Latinx parents of students with dis/abilities experienced the politics of desperation in qualitatively different ways according the areas of the city where they lived. For instance, the uneven geographical development (Harvey, 2006) and the moments of creative destruction (Theodore \& Brenner, 2002) documented in the city of Chicago (Lipman, 2011; NVC, 2014) shaped parents' school selections starting in kindergarten. When entering kindergarten, Black and Latinx parents of students with dis/abilities living in areas of extreme poverty were much more likely to enroll their children in a neighborhood school, parents living in areas of serious decline tended to enroll their children in charter schools, and parents living in areas of gentrification were more likely to enroll their children in magnet schools. The distribution of school actions (e.g., closing a school, opening charter and magnet schools) across areas of the city may have affected students' trajectories, as areas of gentrification tend to contain greater proportions of magnet schools and selective enrollment high schools, while areas of serious decline and extreme poverty contain larger proportions of charter schools. Another possible explanation is that parents living in areas of serious decline, gentrification, and middle class areas (not in extreme poverty) may have the knowledge and time to research other schools in their area (Lubineski \& Weitzel, 2010), and in the case of middle class parents, they may also have the economic means to enroll their children in private schools.

In addition, uneven geographical development shaped the factors considered by Black and Latinx parents of students with dis/abilities when choosing a charter school. With the exception of parents living in middle class areas, safety was the single most important factor contributing to parents' school decisions, even more important than special education services. Indeed, though many parents asked the charter school if they could serve their children with dis/abilities, they did not have firsthand knowledge about the special education services in the school, but they did know about charter school's reputation for strict disciplinary policies and academic achievement.

How Black and Latinx parents of students with dis/abilities constructed their knowledge about safety in neighborhood schools varied across areas of the city. Parents living in middle class areas did not mention safety as a factor for enrolling in charter schools. This can be explained by the fact that these communities were able to maintain their economic status over time. Black and Latinx families living in areas of extreme poverty or serious decline are more vulnerable to the backlash of the uneven geographical development taking place in urban centers. Urban development strategies such as gentrification, the abandonment of certain areas, and the demolition of public housing have an effect in how parents experienced safety in their neighborhoods, particularly those parents living in areas of extreme poverty and serious decline. As gentrification and the demolition of public housing relocated Black families to areas further south and west of the city center, perceptions of neighborhood and school safety changed for parents living in those areas. For parents who could stay in areas of gentrification, the demographic changes they saw in their neighborhoods did not eclipse their earlier experiences in the neighborhood and their perceptions of neighborhood schools. 
While Black and Latinx parents of students with dis/abilities living in areas of extreme poverty had experienced firsthand violence in neighborhood schools, parents living in areas of serious decline and gentrification build their understanding of safety through their experiences of gang violence in their neighborhoods and the symbols and discursive practices attached to neighborhood schools. Safety took particular significance for our participants, as they were concerned that their children with dis/abilities were more vulnerable to experiencing violence in schools ill equipped to meet their children's' needs. This knowledge construction of unsafety is also related to the historical pathologization of schools serving low income students of color through low-test-score stigmatization and the transformation of such schools into prison-like spaces containing metal detectors and security guards. It is this kind of pathologization that is then transferred to the families attending such schools, as parents living in areas of serious decline and gentrification referred to the environment created by the parents and students attending the neighborhood school as a reason to enroll their children in a charter schools. Further, it is this kind of pathologization that justifies the closing of such schools and the "renewal" of those areas through gentrification efforts.

Black and Latinx parents of students with dis/ability living in areas of extreme poverty experienced selective inclusionism. They experienced firsthand an under resourced special education system as well as turnaround schools that produced inconsistencies that affected the services received by their children. Due to austerity measures and school destabilization (Lipman, 2003), students with dis/abilities are required to thrive in exclusionary spaces informed by the ideological work of whiteness, smartness, and goodness with little support. Thus, the poor and scarce services for students with dis/abilities, the destabilization and disinvestment in neighborhood schools, and experiencing violence left Black and Latinx parents of students with dis/abilities with limited options.

Black and Latinx parents living in middle class areas were the only ones concerned with segregation issues. This interesting finding deserves further research. A possible explanation is that this effort to have their children included in general education classroom is a social class strategy (Ball, 2003). Black and Latinx parents living in middle class areas wanted their children to have an equal opportunity to learn in the general education classroom and consequently to have an education that would prepare their children for the market economy. Yet, they experienced school spaces that, informed by selective inclusionism, did not deem their children integrable to the general education classroom. Similar to Rollock, Gillborn, Vincent, and Ball (2015), we found that racist and ableist processes that serve to oppress poor and working class Black and Latinx families also operate to oppress Black and Latinx middle class families of students with dis/abilities - even when the latter families leverage their economic and social capital (e.g., access and funding to attend a private school). As we discussed in the introduction of the paper, CPS has long history of segregating students with dis/abilities. These segregation practices were influenced by a lack of resources for including students with dis/abilities (e.g., teacher aides, training) and by deficit views of dis/abilities. The experiences of Black and Latinx families of students with dis/abilities living in middle class areas with these segregation practices pushed these families into the charter sector.

Charter schools presented several promises to Black and Latin@ parents of students with dis/abilities. The major force of gravity towards a charter school was its reputation for small teacherstudent ratio. This signaled to parents the promise of a more individualized attention and instruction as well as inclusion in the general education classroom. Further, charter schools promised a safe space and the so coveted access to college; they offered the promise of overcoming dis/ability and being deemed as integrable to the market economy.

Yet, as Mitchell (2015, p. II) warns us, "any openings neoliberalism creates for acceptance of formerly excluded populations come at a cost." Indeed, all parents we interviewed continued to 
experience different forms of exclusion in the charter school, an aspect of our study that we examine in depth in a future publication (Waitoller, 2017a). For now, it is worth noting that these forms of exclusion generated a typology of ironies (Waitoller, 2017b). The children of parents who were attracted to the charter school due to the rigorous disciplinary and academic practices, eventually experienced exclusion due to these same inflexible practices. These practices did not account for or adapt to the unique characteristics of students with dis/abilities. Many of these children were repeatedly suspended, some were expelled, while others developed anxiety issues as a result of the pressure to conform to such rigid and normalizing standards of behavior and academic achievement. Parents who were attracted to charter schools due to their promises of small student-teacher ratios, which signaled the opportunity for inclusion and more individualized attention, experienced exclusion due the lack of qualified personnel and capacity to serve the unique needs of their children. Rebecca, for instance, was repeatedly advised by charter school administration to move her son to a more segregated environment in a neighborhood school and had to take the charter school to court until her child was allowed to stay. Angela was asked to stay for part of the day to help her daughter in the classroom since the charter school did not have teacher aides. She was also asked to take her daughter home after lunchtime. In the end, the vast majority of parents we interviewed found themselves engaging again with the politics of desperation as the promises of charter schools vanished and they needed to rethink their schooling options once more.

In conclusion, positioning Black and Latinx parents of students with dis/abilities as empowered individuals and rational consumers dehistoricizes and decontextualizes their agency (Pedroni, 2005). It ignores that such agency operates within inequitable material and discursive relations of race, class, and ability that inhabit neighborhoods and schools (Pedroni, 2005). Under these circumstances, any examination of parents of color engaging with school choice needs to account for the historical conditions in which these parents have experienced public schools in urban centers (Pedroni, 2005). In the case of Black and Latinx parents of students with dis/abilities, this examination needs to focus on how the restructuring of the urban space and the intersecting ideological work of whiteness, smartness, and goodness have created normative school spaces that push parents to engage with the politics of desperation rather than with school choice.

\section{Acknowledgements}

This research was funded by the Institute for Research on Race and Public Policy at the University of Illinois at Chicago. We are grateful to Pauline Lipman, David Stovall, and Michael Thomas for their invaluable feedback at different stages of the research project. We are also grateful to EPAA anonymous reviewers who contributed to the quality of our paper. We acknowledge the work of Chris Poulos in creating the maps presented in this article. Finally, we are particularly grateful to the Black and Latinx parents of students with dis/abilities in our study who shared their stories with us.

\section{References}

Annamma, S. A., Connor, D. J., \& Ferri, B. A. (2013). Dis/ability critical race studies (DisCrit): Theorizing at the intersections of race and dis/ability. Race, Ethnicity \& Education, 16(1), 1-31.

Apple, M. W. (2001). Educating the "right" way: Markets, standards, god, and inequality. New York: RoutledgeFalmer.

Ball, S. J. (1997). Policy sociology and critical social research: A personal review of recent education policy and policy research. British Educational Research Journal, 23(3), 257-274. https://doi.org/10.2307/1502044 
Ball, S. J. (2006). Education policy and social class: The selected works of Stephen J. Ball. London: Routledge.

Bell, C. (2009). Geography in parental choice. American Journal of Education, 115(4), 493-521.

Bell, D. (1980). Brown v. Board of Education and the interest convergence dilemma. Harvard Law Review, 93, 518-533.

Blanchett, W. J., Klingner, J. K., \& Harry, B. (2009). The intersection of race, culture, language, and disability: Implications for urban education. Urban Education, 44(4), 389-409.

Boutot, A. E., \& Myles, B. S. (2016). Autism spectrum disorders: Foundations, characteristics, and effective strategies. New York: Pearson.

Brenner, N., \& Theodore, N. (2002). Cities and the geographies of "actually existing neoliberalism." Antipode, 34(3), 349-379. https://doi.org/10.1111/1467-8330.00246

Broderick, A. A., \& Leonardo, Z. (2016). What a good boy: The deployment and distribution of "goodness" as ideological property of school. In D. J. Connor, B. A. Ferri \& S. Annamma (Eds.), DisCrit: Disabiity Studies and Critical Race Theory in Education (pp. 55-67). New York: Teachers College Record.

Buras, K. L. (2011). Race, charter schools, and conscious capitalism: On the spatial politics of whiteness as property (and the unconscionable assault on black New Orleans). Harvard Educational Review, 81(2), 296-331.

Caref, C., Hainds, S., Hilgendorf, K., Jankov, P., \& Russell, K. (2012). The black and white of education in Chicago's public schools. Retrieved from http://www.ctunet.com/questcenter/research/black-andwhite-of-chicago-education.pdf

Charmaz, K. (2008). Constructing grounded theory. Thousand Oaks, CA: Sage.

Chicago Public Schools. (2016a). Limited English proficiency, special ed, low income, IEP, Schoolyear 2016 2017 (Data file). Retrieved from http://cps.edu/SchoolData/Pages/SchoolData.aspx

Chicago Public Schools. (2016b). Chicago Board of Education Monthly Meeting December 7, 2016 [Video File]. Retrieved from https://www.youtube.com/watch?v=a18CuuJ8_Xc

Chicago Teachers Union Research Department (2015). Special Education Services in Crisis at CPS. Chicago, IL: Chicago Teachers Union. Retrieved from http://www.ctunet.com/blog/newctu-report-special-education-crisis-chicago-public-schools

Chubb, J.E. \& Moe, T.M. (1990). Politics, Markets, and America's Schools. Washington: The Brookings Institution.

Connor, D. J., Ferri, B. A., \& Annamma, S. A. (2016). DisCrit: Disability studies and critical race theory in education. New York, NY: Teachers College Press.

Davis, D.-A. (2007). Narrating the mute: Racializing and racism in a neoliberal moment. Souls 9(4), 346-360.

de la Torre, M., Gordon, M. F., Moore, P., \& Cowhy, J. (2015). School closings in Chicago: Understanding families' choices and constraints for new school enrollment. Chicago: University of Chicago Consortium on Chicago School Research.

Dumas, M. J. (2013). 'Waiting for Superman' to save black people: Racial representation and the official antiracism of neoliberal school reform. Discourse: Studies in the cultural politics of education, 34(4), 531-547.

Education: Donald J. Trump's Vision. (2016). Retrieved from www.donaldjtrump.com/policies/education

Estes, M. B. (2006). Choice for all? Charter schools and students with special needs. The Journal of Special Education, 37(4), 257-267.

Estevan, R. D. (2009). Renaissance 2010 and Students with Disabilities. Chicago, IL: Access Living Center for Service, Advocacy and Social Change for people with Disabilities.

Estevan, R. D. (2016). Chicago Public Schools budget review FY 2017. Chicago, IL: Access Living Center for Service, Advocacy and Social Change for people with Disabilities. 
Fabricant, M., \& Fine, M. (2012). Charter schools and the corporate makeover of public education: What's at stake? New York: Teachers College Press.

Ferguson, A. (2001). Bad boys: Public schools in the making of Black masculinity. Ann Arbor, MI: University of Michigan Press.

Fleming, J., Greenlee, A., Gutstein, E., Lipman, P., \& Smith, J. (2009, February). Examining CPS'plan to close, consolidate, turn-around 2 schools. Data and Democracy Project: Investing in Neighborhoods (Research Paper Series, Paper No. 2). Chicago, IL: Collaborative for Equity and Justice in Education and Nathalie P. Voorhees Center for Neighborhood and Community Improvement, University of Illinois-Chicago.

Garcia, D. R. (2008). Academic and racial segregation in charter schools: Do parents sort students into specialized charter schools?. Education and Urban Society, 40(5), 590-612.

Garcy, A. M. (2011). High expense: Disability severity and charter school attendance in Arizona. Education Policy Analysis Archives, 19(6), 1-26.

Goodley, D. (2014). Dis/ability Studies: Theorizing disableism and ableism. London: Routledge.

Government Accountability Office. (2012). Charter Schools: Additional Federal Attention Needed to Help Protect Access for Students with Disabilities. (GAO-12-543). Washington DC. Retrieved from http://www.gao.gov/products/GAO-12-543.

Greenlee, A., Hudspeth, N., Lipman, P., Smith, D.A., \& Smith, J. (2008). Examining CPS' plan to close, consolidate, turn around 18 schools. Data and Democracy Project: Investing in

Neighborhoods (Research Paper Series, Paper No. 1). Chicago, IL: Collaborative for Equity and Justice in Education and Nathalie P. Voorhees Center for Neighborhood and Community Improvement, University of Illinois at Chicago. Retrieved from

Gwynne, J., \& de la Torre, M. (2009). When schools close: Effects on displaced students in Chicago Public Schools. Consortium on Chicago School Research, University of Chicago.

Harris, C. (1993). Whiteness as property. Harvard Law Review, 106(8), 1707-1791. https://doi.org/10.2307/1341787

Harry, B., \& Klingner, J. K. (2006). Why are so many minorities in special education? Understanding race and disability in schools. New York: Teachers College Press.

Harvey, D. (2005). A brief history of neoliberalism. Oxford: Oxford University Press.

Harvey, D. (2006). Spaces of global capitalism: Towards a theory of uneven geographical development. New York: Verso.

Harvey, D. (2008). Social justice and the city (2nd ed.). Athens, GA: The University of Georgia Press.Hatt, B. (2012). Smartness as a Cultural Practice in Schools. American Educational Research Journal, 49(3), 438-460.

Lincoln, Y. S., \& Guba, E. G. (1985). Naturalistic inquiry. Newbury Park, CA: Sage Publications.

Lange, C. M., \& Lehr, C. A. (2000). Charter schools and students with disabilities: Parent perceptions of reasons for transfer and satisfaction with services. Remedial and Special Education, 21, 141-151.

Lipman, P. (2003). Chicago school policy: Regulating Black and Latino youth in the global city. Race, Ethnicity \& Education, 6(4), 331-355.

Lipman, P. (2011). The new political economy of urban education: Neoliberalism, race, and the right to the city. New York: Routledge.

Lipsitz, G. (2007). The racialization of space and the spatialization of race. Landscape Journal, 26(1), $10-23$.

Losen, D. J., Keith, M. A., Hodson, C. L., \& Martinez, T. E. (2016). Charter schools, civil rights and school discipline: A comprehensive review. Civil Rights Project-Proyecto Derechos Civiles. 
Lubienski, C. A., \& Weitzel, P. C. (2010). Information use and epidemics in charter school policy. In C. A. Lubienski \& P. C. Weitzel (Eds.), The charter school experiment: Expectations, evidence, and implications (pp. 197-218). Cambridge, MA: Harvard Education Press.

Manno, Finn \& Vanourek (1999). Charter schools: Serving disadvantaged youth. Education and Urban Society, 31(4), 429-445.

Mitchell, D. (2015). The biopolitics of disability: Neoliberalism ablenationalism, and peripheral embodiment. Ann Arbor, Michigan: The University of Michigan Press.

Nathalie P. Voorhees Center for Neighborhood and Community Improvement at the University of Illinois at Chicago. (2014). The socioeconomic change of Chicago's community areas (1970-2014). Retrieved from http://www.voorheescenter.com/\#!gentrification-index/ccmx.

National Center for Education Statistics. (2014). The Condition of Education 2014. Washington, DC. Retrieved from http:/ / nces.ed.gov/pubsearch/pubsinfo.asp?pubid=2014083.

Omi, M., \& Winant, H. (2015). Racial formation in the United States (3rd ed.). New York: Routledge.

Ong-Dean, C. (2009). Distinguishing disability: Parents, privilege, and special education. Chicago, IL: University of Chicago Press.

Payls, T. (2008). Purposive sampling. In L. M. Given (Ed.), The Sage encyclopedia of qualitative methods (pp. 697-698). Los Angeles: Sage.

Pedroni, T. (2005). Market movements and the dispossessed: Race, identity, and subaltern agency among Black women voucher advocates. The Urban Review, 37(2), 83-106.

Pedroni, T. (2007). Market movements: African American involvement in school voucher reform. New York: Routledge

Rhim, L. M., Gumz, J., \& Henderson, K. (2015). Key trends in special education in charter schools: A secondary analysis of the civil rights data collection 2011-2012. National Center for Special Education in Charter Schools. Retrieved from http://static1.squarespace.com/static/52feb326e4b069fc72abb0c8/t/564109d3e4b027fb79 1d1964/1447102931798/crdc_full.pdf

Rhim, L. M., \& McLaughlin, M. (2007). Students with disabilities in charter schools: What we now know. Focus on Exceptional Children, 39(5), 1-12.

Rowe, E. E., \& Lubienski, C. (2016). Shopping for schools or shopping for peers: Public schools and catchment area segregation. Journal of Education Policy, 1-17. https.//doi.org/10.1080/02680939.2016.1263363

Sassen, S. (2005). The global city: Introducing a concept. The Brown Journal of World Affairs, 11(2), 2743.

Setren, E. (2015). Special education and English language learner students in Boston charter schools: Impact and classification. Cambridge, MA: School Effectiveness \& Inequality Initiative at Massachusetts Institute of Technology. Retrieved from https://seii.mit.edu/research/study/specialeducation-and-english-language-learner-students-in-boston-charter-schools-impact-andclassification/

Shildrick, M. (2012). Dangerous discourses of disability, subjectivity and sexuality. New York: Palgrave McMillan.

Skiba, R. J., Artiles, A. J., Kozleski, E. B., Losen, D. J., \& Harry, E. G. (2016). Risks and consequences of oversimplifying educational inequities: A response to Morgan et al. (2015). Educational Researcher, 45(3), 221-225.

Smith, J. J., \& Stovall, D. (2008). 'Coming home' to new homes and new schools: Critical race theory and the new politics of containment. Journal of Education Policy, 23(2), 135-152. https:/ / doi.org/10.1080/02680930701853062

Soja, E. W. (1989). Postmodern geographies: The reassertion of space in critical social theory. New York: Verso. 
Soja, E. W. (1996). Thirdspace: Journeys to Los Angeles and other real-and-imagined places. Oxford: Basil Blackwell.

Soja, E. W. (2010). Seeking spatial justice. Minneapolis: University of Minnesota Press.

Stovall, D. (2013). Against the politics of desperation: Educational justice, critical race theory, and Chicago school reform. Critical Studies in Education, 54(1), 33-43. https://doi.org/10.1080/17508487.2013.739192

Strauss, A. L., \& Corbin, J. (1990). Basics of qualitative research: Grounded Theory procedures and techniques. Newbury Park, CA: Sage.

Varenne, H., \& McDermott, R. (1998). Successful failure: The school America builds. Boulder, CO: Westview Press.

Waitoller, F. R. (in press). Why are we not more inclusive? An analysis of neoliberal selective inclusionism. In C. Boyle., S. Mavropoulou., J. Anderson, \& A. Page (Eds.), Inclusive Education: Global Issues \& Controversies. Rotterdam: Sense Publishers.

Waitoller. F. R. (2017a). Neoliberal selective inclusionism: Understanding steering away practices in charter schools. Manuscript in preparation.

Waitoller. F. R. (2017b, April). The irony of rigor: Steering away Black and Latinx students with dis/abilities from charter schools. American Educational Research Association Annual Meeting, San Antonio.

Waitoller, F. R., Maggin, D. M., \& Trzaska, A. (2017). A longitudinal comparison of enrollment patterns of students receiving special education in urban neighborhood and charter schools. Journal of Disability Policy Studies, 28(1), 3-13.

Weber, R. (2015). From boom to bubble: How finance built the new Chicago. Chicago: University of Chicago Press.

Weber, R., Farmer, S., \& Donaghue, M. (2016). Why these schools: Explaining closures in Chicago, 20002013. Chicago, IL: Great Cities Institute, University of Illinois at Chicago. Retrieved from https://greatcities.uic.edu/2017/01/10/why-these-schools-explaining-school-closures-inchicago-2000-2013/

Welner, K., \& Howe, K. (2005). Steering toward separation: The policy and legal implications of "counseling" special education students away from choice schools. In J. Scott (Ed.), School choice and student diversity: What the evidence says (pp. 93-111). New York: Teachers College Press.

Wilkens, C. P. (2011). Students with disabilities in urban Massachusetts charter schools. Teachers College Record, ID Number: 16389. Retrieved from http:/ / www.tcrecord.org/Content.asp?ContentId=16389

Winters, M. A. (2015). Understanding the gap in special education enrollments between charter and traditional public schools: Evidence from Denver, Colorado. Educational Researcher, 44(4), 228-236. 


\section{About the Authors}

\section{Federico R. Waitoller}

University of Illinois at Chicago

fwaitoll@,uic.edu

Dr. Waitoller is an assistant professor in the department of special education at the University of Illinois at Chicago. His research focuses on urban inclusive education. In particular, he examines how neoliberal informed polices, such as top-down accountability, portfolio district models, and school choice converge with inclusive education efforts, and how these initiatives affect Black and Latinx students with dis/abilities. His research also examines teacher learning efforts and pedagogies for inclusive education.

\section{Gia Super}

University of Illinois at Chicago

gsuper2@,uic.edu

Gia Super is a doctoral student in the department of Educational Policy Studies at the University of Illinois at Chicago. Her research interests include students with dis/abilities, bilingual education, and teacher preparation in the context of neoliberal education reform. She is a former teacher in the Chicago Public Schools and a parent of a child with a dis / ability navigating special education in the district.

\section{About the Guest Editors}

\section{Federico R. Waitoller}

University of Illinois at Chicago

fwaitoll@,uic.edu

Dr. Waitoller is an assistant professor in the department of special education at the University of Illinois at Chicago. His research focuses on urban inclusive education. In particular, he examines how neoliberal informed polices, such as top-down accountability, portfolio district models, and school choice converge with inclusive education efforts, and how these initiatives affect Black and Latinx students with dis/abilities. His research also examines teacher learning efforts and pedagogies for inclusive education.

\section{Rhoda Rae Gutierrez}

University of Illinois at Chicago

rrgutier@uic.edu

Rhoda Rae Gutierrez is a doctoral candidate in Educational Policy Studies at the University of Illinois at Chicago. Her research interests include neoliberal education policy, cultural politics of race, and social justice. She is a researcher with the Collaborative for Equity and Justice in Education and a parent activist. 


\section{SPECIAL ISSUE
Restructuring and Resisting Education
Reforms in Chicago's Public Schools education policy analysis archives \\ Volume 25 Number 55 \\ June 5, 2017 \\ ISSN 1068-2341}

\section{@)}

SOMERIIGHISRESERVED Readers are free to copy, display, and distribute this article, as long as the work is attributed to the author(s) and Education Policy Analysis Archives, it is distributed for noncommercial purposes only, and no alteration or transformation is made in the work. More details of this Creative Commons license are available at http://creativecommons.org/licenses/by-nc-sa/3.0/. All other uses must be approved by the author(s) or EPAA. EPAA is published by the Mary Lou Fulton Institute and Graduate School of Education at Arizona State University Articles are indexed in CIRC (Clasificación Integrada de Revistas Científicas, Spain), DIALNET (Spain), Directory of Open Access Journals, EBSCO Education Research Complete, ERIC, Education Full Text (H.W. Wilson), QUALIS A1 (Brazil), SCImago Journal Rank; SCOPUS, SOCOLAR (China).

Please send errata notes to Audrey Amrein-Beardsley at Audrey.beardsley@asu.edu

Join EPAA's Facebook community at https://www.facebook.com/EPAAAAPE and Twitter feed@epaa_aape. 


\section{education policy analysis archives editorial board}

Lead Editor: Audrey Amrein-Beardsley (Arizona State University)

Editor Consultor: Gustavo E. Fischman (Arizona State University)

Associate Editors: David Carlson, Margarita Jimenez-Silva, Eugene Judson, Mirka Koro-Ljungberg, Scott

Marley, Jeanne M. Powers, Iveta Silova, Maria Teresa Tatto (Arizona State University)

Cristina Alfaro San Diego State

University

Gary Anderson New York

University

Michael W. Apple University of Wisconsin, Madison

Jeff Bale OISE, University of

Toronto, Canada

Aaron Bevanot SUNY Albany

David C. Berliner Arizona

State University

Henry Braun Boston College

Casey Cobb University of

Connecticut

Arnold Danzig San Jose State

University

Linda Darling-Hammond

Stanford University

Elizabeth H. DeBray University of

Georgia

Chad d'Entremont Rennie Center for Education Research \& Policy

John Diamond University of Wisconsin, Madison

Matthew Di Carlo Albert Shanker Institute

Michael J. Dumas University of California, Berkeley

Kathy Escamilla University of Colorado, Boulder

Melissa Lynn Freeman Adams State College

Rachael Gabriel

University of Connecticut

Amy Garrett Dikkers University of North Carolina, Wilmington

Gene V Glass Arizona

State University
Ronald Glass University of California, Santa Cruz

Jacob P. K. Gross University of Louisville

Eric M. Haas WestEd

Julian Vasquez Heilig California State University, Sacramento

Kimberly Kappler Hewitt University of North Carolina Greensboro

Aimee Howley Ohio University

Steve Klees University of Maryland

Jaekyung Lee

SUNY Buffalo

Jessica Nina Lester

Indiana University

Amanda E. Lewis University of Illinois, Chicago

Chad R. Lochmiller

Indiana University

Christopher Lubienski

Indiana University

Sarah Lubienski University of Illinois, Urbana-Champaign

William J. Mathis University of Colorado, Boulder

Michele S. Moses University of Colorado, Boulder

Julianne Moss Deakin

University, Australia

Sharon Nichols University of Texas, San Antonio

Eric Parsons University of Missouri-Columbia

Susan L. Robertson Bristol University, UK

Gloria M. Rodriguez

University of California, Davis
R. Anthony Rolle University of Houston

A. G. Rud Washington State University

Patricia Sánchez University of University of Texas, San Antonio

Janelle Scott University of California, Berkeley

Jack Schneider College of the Holy Cross

Noah Sobe Loyola University

Nelly P. Stromquist University of Maryland

Benjamin Superfine University of Illinois, Chicago

Sherman Dorn

Arizona State University

Adai Tefera Virginia

Commonwealth University

Tina Trujillo University of

California, Berkeley

Federico R. Waitoller University of Illinois, Chicago

Larisa Warhol

University of Connecticut

John Weathers University of Colorado, Colorado Springs

Kevin Welner University of Colorado, Boulder

Terrence G. Wiley Center for Applied Linguistics

John Willinsky

Stanford University

Jennifer R. Wolgemuth University of South Florida

Kyo Yamashiro Claremont Graduate University 


\section{archivos analíticos de políticas educativas consejo editorial}

Editor Consultor: Gustavo E. Fischman (Arizona State University)

Editores Asociados: Armando Alcántara Santuario (Universidad Nacional Autónoma de México), Jason Beech (Universidad de San Andrés), Angelica Buendia (Metropolitan Autonomous University, México), Ezequiel Gomez Caride (Pontificia Universidad Católica Argentina), Antonio Luzon (Universidad de Granada), José Luis Ramírez (Universidad de Sonora, Mexico)

Claudio Almonacid

Universidad Metropolitana de Ciencias de la Educación, Chile

Miguel Ángel Arias Ortega Universidad Autónoma de la

Ciudad de México

Xavier Besalú Costa

Universitat de Girona, España

Xavier Bonal Sarro Universidad Autónoma de Barcelona, España

Antonio Bolívar Boitia

Universidad de Granada, España

José Joaquín Brunner Universidad Diego Portales, Chile

Damián Canales Sánchez

Instituto Nacional para la

Evaluación de la Educación, México

Gabriela de la Cruz Flores

Universidad Nacional Autónoma de México

Marco Antonio Delgado Fuentes

Universidad Iberoamericana,

México

Inés Dussel, DIE-CINVESTAV, México

Pedro Flores Crespo Universidad

Iberoamericana, México

Ana María García de Fanelli Centro de Estudios de Estado y Sociedad (CEDES) CONICET, Argentina
Juan Carlos González Faraco

Universidad de Huelva, España

María Clemente Linuesa

Universidad de Salamanca, España

Jaume Martínez Bonafé

Universitat de València, España

Alejandro Márquez Jiménez

Instituto de Investigaciones sobre la

Universidad y la Educación, UNAM,

México

María Guadalupe Olivier Tellez,

Universidad Pedagógica Nacional, México

Miguel Pereyra Universidad de

Granada, España

Mónica Pini Universidad Nacional de San Martín, Argentina

Omar Orlando Pulido Chaves

Instituto para la Investigación

Educativa y el Desarrollo Pedagógico (IDEP)

José Luis Ramírez Romero

Universidad Autónoma de Sonora, México

Paula Razquin Universidad de San

Andrés, Argentina

José Ignacio Rivas Flores

Universidad de Málaga, España
Miriam Rodríguez Vargas

Universidad Autónoma de

Tamaulipas, México

José Gregorio Rodríguez

Universidad Nacional de

Colombia, Colombia

Mario Rueda Beltrán Instituto

de Investigaciones sobre la

Universidad y la Educación,

UNAM, México

José Luis San Fabián Maroto

Universidad de Oviedo,

España

Jurjo Torres Santomé,

Universidad de la Coruña, España

Yengny Marisol Silva Laya

Universidad Iberoamericana,

México

Juan Carlos Tedesco

Universidad Nacional de San

Martín, Argentina

\section{Ernesto Treviño Ronzón}

Universidad Veracruzana, México

Ernesto Treviño Villarreal

Universidad Diego Portales

Santiago, Chile

Antoni Verger Planells

Universidad Autónoma de

Barcelona, España

Catalina Wainerman

Universidad de San Andrés, Argentina

Juan Carlos Yáñez Velazco

Universidad de Colima, México 


\section{arquivos analíticos de políticas educativas conselho editorial \\ Editor Consultor: Gustavo E. Fischman (Arizona State University) Editoras Associadas: Geovana Mendonça Lunardi Mendes (Universidade do Estado de Santa Catarina), Marcia Pletsch, Sandra Regina Sales (Universidade Federal Rural do Rio de Janeiro)}

\author{
Almerindo Afonso \\ Universidade do Minho \\ Portugal \\ Rosanna Maria Barros Sá \\ Universidade do Algarve \\ Portugal
}

\section{Maria Helena Bonilla \\ Universidade Federal da Bahia \\ Brasil}

Rosa Maria Bueno Fischer

Universidade Federal do Rio Grande

do Sul, Brasil

\section{Alice Casimiro Lopes \\ Universidade do Estado do Rio de \\ Janeiro, Brasil}

\section{Suzana Feldens Schwertner \\ Centro Universitário Univates Brasil}

Flávia Miller Naethe Motta Universidade Federal Rural do Rio de Janeiro, Brasil

\author{
Alexandre Fernandez Vaz \\ Universidade Federal de Santa \\ Catarina, Brasil
}

\section{Regina Célia Linhares Hostins \\ Universidade do Vale do Itajaí, Brasil}

\section{Alfredo Macedo Gomes}

Universidade Federal de Pernambuco Brasil

\section{Jefferson Mainardes}

Universidade Estadual de Ponta

Grossa, Brasil

Jader Janer Moreira Lopes

Universidade Federal Fluminense e

Universidade Federal de Juiz de Fora,

Brasil

Debora Nunes

Universidade Federal do Rio Grande do Norte, Brasil

\section{Alda Junqueira Marin \\ Pontifícia Universidade Católica de São Paulo, Brasil}

\section{Dalila Andrade Oliveira}

Universidade Federal de Minas

Gerais, Brasil
José Augusto Pacheco

Universidade do Minho, Portugal

Jane Paiva

Universidade do Estado do Rio de Janeiro, Brasil

Paulo Alberto Santos Vieira

Universidade do Estado de Mato

Grosso, Brasil

Fabiany de Cássia Tavares Silva Universidade Federal do Mato

Grosso do Sul, Brasil

\section{António Teodoro}

Universidade Lusófona

Portugal

\section{Lílian do Valle}

Universidade do Estado do Rio de Janeiro, Brasil

\section{Alfredo Veiga-Neto}

Universidade Federal do Rio

Grande do Sul, Brasil 